\title{
Seasonal physiology and ecology of Antarctic marine benthic predators and scavengers
}

\author{
Birgit E. Obermüller, Simon A. Morley*, David K. A. Barnes, Lloyd S. Peck
}

British Antarctic Survey, Natural Environment Research Council, Madingley Road, Cambridge CB3 0ET, UK

\begin{abstract}
Pronounced seasonality in photoperiod and phytoplankton availability drives key physiological processes in many Antarctic primary consumers. To test the hypothesis that carnivores would be less markedly affected by environmental seasonality than benthic 'herbivores', we measured faecal egestion, oxygen consumption and nitrogen excretion every 2 to 3 mo for 18 mo in 5 benthic predators and scavengers common around Adelaide Island (West Antarctic Peninsula): the fish Harpagifer antarcticus, the brittle star Ophionotus victoriae, the nemertean Parborlasia corrugatus, the amphipod Paraceradocus miersii and the nudibranch Doris kerguelenensis. The degree of seasonality varied between species and was not consistent across the physiological parameters measured. Faecal egestion varied strongly between species and individuals. All species except Paraceradocus miersii ceased feeding for several months. No consistent seasonality in metabolic activity (oxygen consumption and nitrogen excretion) was observed, and seasonal factorial changes in oxygen consumption were less than in primary consumers. Use of metabolic substrates changed between seasons, particularly in $H$. antarcticus, which switched from a balanced diet to mainly protein utilisation at the start of winter. O. victoriae had the highest O:N ratio (232) and Parborlasia corrugatus the lowest (9), suggesting the latter species is the most exclusive carnivore. We conclude that food availability and quality is also variable for Antarctic secondary consumers but that this variation is not as tightly coupled to the environmental seasonality as in primary consumers. Other factors, such as reproductive activity, that are indirectly coupled to seasonal signals may have also been causing this variability.
\end{abstract}

KEY WORDS: Seasonality $\cdot$ Feeding activity $\cdot$ Metabolic activity $\cdot$ O:N ratio $\cdot$ Metabolic substrate Polar benthos $\cdot$ Secondary consumers

\section{INTRODUCTION}

Studies of effects of, and adaptation to, the environment are dominated by investigations of temperature. However, other factors such as photoperiod, water availability, food availability, wind speed and salinity can have major impacts on animal physiology and life histories. Furthermore, the seasonal changes in these characteristics, as well as temperature, strongly influence the ecological periodicity of animals and plants, and this varies strongly with latitude. For many decades the paradigm has been that activities of marine organisms become more seasonal from low to high latitudes (e.g. Stott 1934, Harrington 1986, Clarke \& Peck 1991). At low latitudes in the tropics, photoperiod is relatively constant, which in turn leads to only small fluctuations in primary production and temperature throughout the year. As a result, seasonality of feeding, growth and reproduction tends to be reduced and timings are largely determined by local physical conditions (e.g. equatorial upwelling or winter monsoon) (Banse 1987, Longhurst 1993). Periodicity of cues, which can be diel, lunar, monthly or annual (Lobel 1978, Tanner 1996), becomes more important in environments with reduced seasonality. For example, mysid shrimps in the Merbok mangrove estuary (Malaysia) show continuous reproduction throughout the year and the observed high fluctuations in abundance do not correlate with temperature and salinity (Hanamura et al. 2008). In contrast, food availability, consumption, growth and reproduction in temperate and polar regions are markedly seasonal (Peck et al. 
2006). Both temporal patterns, seasonality and periodicity, govern processes across latitudes (Pearse 1965, Reed 1995).

Seasonality, which has been historically dominated by studies in cold temperate seas, is complex and its effects on organisms vary from region to region, as do the most important factors affecting animal physiologies. Most benthic suspension feeders show an increase in activity, secondary production and reproductive activity during spring and summer, a decrease in autumn, and a minimum in winter, with some species hibernating, or showing periods of markedly reduced metabolic activity (e.g. see Gruzov 1977, Hughes 1989, Fenchel 1990). Temperature and food availability in temperate regions tend to be positively correlated, and are both low during winter (increased depth of mixed layer and low irradiance). Species from the warm temperate Mediterranean Sea on the other hand, where temperature and food are often temporally decoupled, show different patterns. For example, most benthic hydrozoans, some colonial ascidians, bivalves and anthozoans reproduce in spring or autumn but grow between autumn and spring in the Mediterranean Sea with a decrease in activity during summer (see Turon 1992, Ramon et al. 1995, Coma et al. 1998, 2000). However, there is a mixture of strategies with solitary ascidians and some sponges having their highest rates of reproduction and growth during summer months (Becerro \& Turon 1992). In contrast to cold temperate environments, temperature plays a minor role, and factors controlling seasonality in warm temperate seas are stratification, mixing periods, and energy shortage, i.e. depleted food supply such as suspended materials (Coma et al. 1998).

At polar latitudes, coastal summer phytoplankton blooms can be very intense, but for the majority of the year, standing stocks of chlorophyll are $<1 \mu \mathrm{g} \mathrm{l}^{-1}$ (Clarke \& Leakey 1996, Clarke et al. 2008). Feeding, growth and the transfer of energy to reproduction (gonad production and gametogenesis) in primary consumers are often coupled with the brief austral summer and many suspension and deposit feeders reduce feeding and metabolic activity for several months during the winter (Gruzov 1977, Whitaker 1982, Clarke 1988, Clarke et al. 1988, Brockington \& Peck 2001, Morley et al. 2007). Some bryozoans even undergo a degree of winter dormancy during which most organic tissues are reabsorbed (Barnes \& Peck 2005). However at least one species, the Antarctic brachiopod Liothyrella uva, appears to decouple periods of feeding from growth (Peck et al. 1997). Timings and duration of reproduction can be very varied even within a guild, e.g. sessile suspension feeders (see Bowden et al. 2006). The timing of reproductive cycles may be geared either to the summer feeding of adults, or to the feeding require- ments of newly emerged larvae (Pearse et al. 1991) or settling juveniles, which in sessile suspension-feeding taxa is uncoupled from the summer plankton bloom (Bowden et al. 2009). There is still some debate over the relative importance of resource limitation and the low but stable temperatures in determining the slow growth characteristic of marine organisms living in polar regions, but seasonality has clear and powerful effects (Clarke et al. 2004, Heilmayer et al. 2004, Barnes et al. 2007).

Traditional concepts of summer-winter ecophysiological change, however, are not straightforward, even in Antarctic primary consumers. Extreme variability may be found in sessile suspension feeders, where most species exhibit strong seasonal physiology. Examples can be found among bryozoans, where some species stay active and feed for half to most of the year, and periods of reduced metabolic and feeding activity can be as short as 1 mo (Barnes \& Clarke 1994, 1995, also Peck et al. 2005 for brachiopods). It would be expected that higher trophic-level groups within the food web, such as predators and scavengers, may have biological patterns that are less coupled to the overlying seasonality (Clarke 1988). From the few predators and scavengers studied to date, the extent of seasonality varies between species, and is not taxonomically controlled. Gastropods and echinoderms for example exhibit a broad range of seasonal strategies (Picken 1980 and Pearse et al. 1985, 1991 respectively).

We hypothesise that because food supply for secondary consumers is less temporally variable (over winter to summer) than for herbivores, Antarctic carnivores should in general be much less seasonal in feeding and related (e.g. metabolic) activities. To test this hypothesis we monitored physiological changes for a winter-summer signal throughout the year in 5 common and abundant predators and scavengers. These were: the notothenid fish Harpagifer antarcticus, the brittle star Ophionotus victoriae, the nemertean worm Parborlasia corrugatus, the gammarid amphipod Paraceradocus miersii and the nudibranch Doris kerguelenensis. These species are abundant and widespread members of Antarctic near-shore marine communities, represent several major faunal taxa, encompass different habitats, and cover a range of diets, from very specialised to broadly generalistic. Here we present results on seasonal changes in oxygen consumption, nitrogen excretion and faecal egestion.

\section{MATERIALS AND METHODS}

Collection of specimens. Between February 2007 and March 2008 individuals of each of 5 species of benthic marine carnivore/scavenger were hand-collected 
every 2 to 3 mo by SCUBA divers at shallow sampling sites (5 to 20 m depth) near Rothera Research Station, Adelaide Island, Antarctica $\left(67^{\circ} 34^{\prime} \mathrm{S}, 6^{\circ} 07^{\prime} \mathrm{W}\right.$; Fig. 1A). The notothenid fish Harpagifer antarcticus was sampled in East Beach (Fig. 1B), a coastal area east of the station. The brittle star Ophionotus victoriae, the nemertean worm Parborlasia corrugatus and the nudibranch Doris kerguelenensis were sampled in

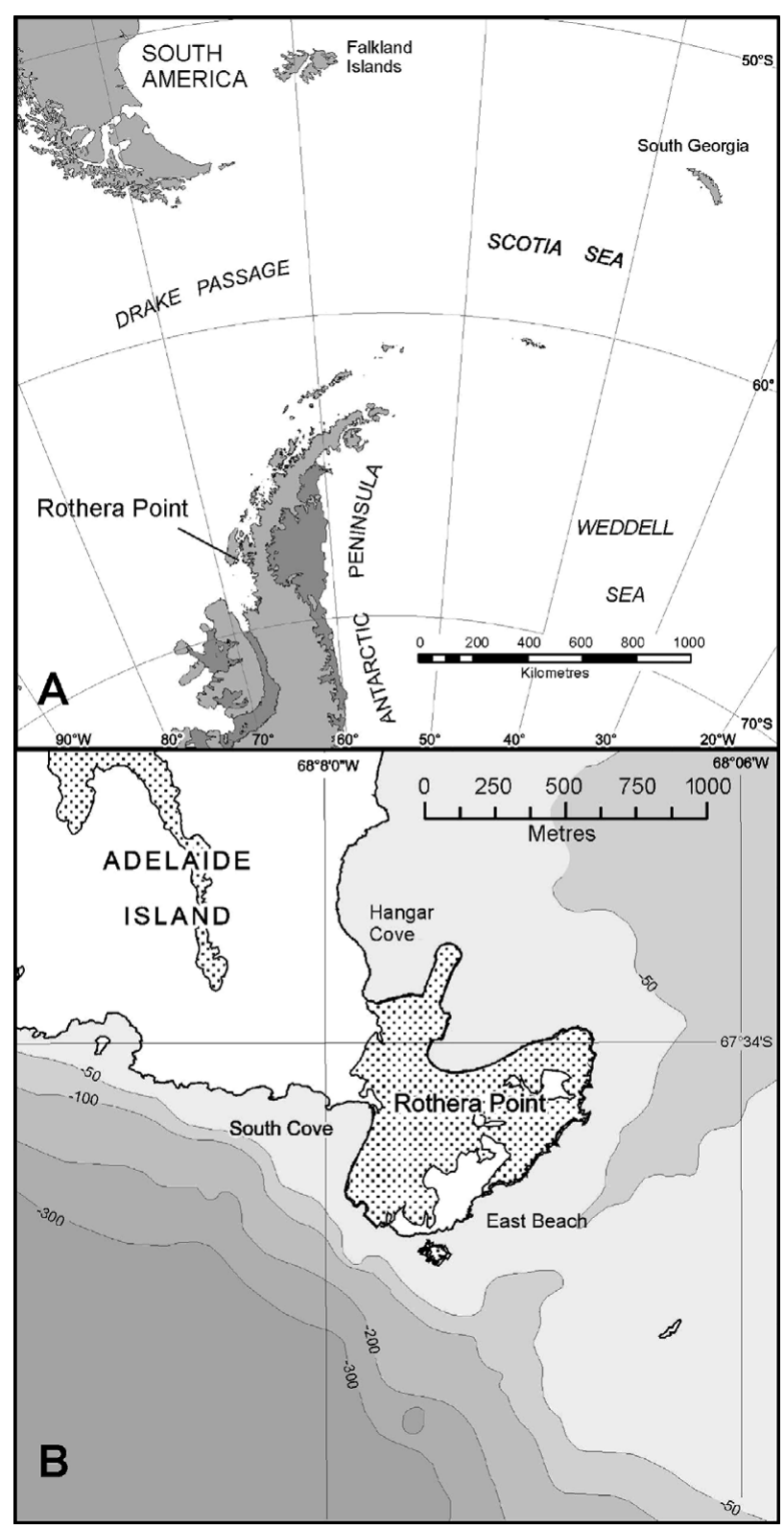

Fig. 1. (A) Position of Rothera Research Station at Rothera Point $\left(67^{\circ} 34^{\prime} \mathrm{S}, 68^{\circ} 07^{\prime} \mathrm{W}\right)$ on southwest Adelaide Island in relation to the Antarctic Peninsula and Southern Ocean. (B) Location of the sampling sites in the shallow waters (5 to $20 \mathrm{~m}$ ) near the Research Station at Rothera Point: Hangar Cove, East Beach and South Cove. The dotted pattern on Adelaide Island marks areas of ice-free exposed rock
Hangar Cove (Fig. 1B), a site north of Rothera Research Station. The gammarid amphipod Paraceradocus miersii was collected in South Cove (Fig. 1B), a site south of the station. A summary of the sampling sites, collection depths and substrate types is given in Table 1. We collected a similar size range of specimens at each sampling event and also tested for significant differences in animal masses throughout the year. Following collection, specimens were immediately transferred to the flow-through aquarium in the laboratory, in order to minimise stress. Water temperatures in the flow-through aquarium ranged (with natural sea temperatures) seasonally from -1.9 to $+1.2^{\circ} \mathrm{C}$ over the year.

Faecal egestion. We measured faecal egestion during the first $48 \mathrm{~h}$ after collection. Immediately after collection, 6 specimens of each species were placed individually in buckets with a mesh bottom containing filtered seawater $(53 \mu \mathrm{m})$. The water was changed after $24 \mathrm{~h}$ and faeces were collected over a period of $48 \mathrm{~h}$, briefly rinsed in distilled water, and faeces dry mass (FDM) and ash-free dry mass (AFDM) were measured in accordance with the protocol used in Clarke (1990) and Fraser et al. (2002). Faecal egestion was expressed as mg FDM per $g$ animal wet mass (AWM) per $24 \mathrm{~h}\left(\mathrm{mg} \mathrm{g}^{-1} \mathrm{~d}^{-1}\right)$. At the end of each trial whole AWM of each individual was determined after a brief rinse in distilled water and surface-drying with a tissue. Where possible, specimen size was measured (total body length in notothenid fish, gammarid amphipods and nudibranchs; mean disc diameter in brittle stars). No length measurements were taken in nemertean worms as their bodies can contract or elongate significantly, either naturally or in response to external stimuli (Gibson 1983). Measurements in nudibranchs should be regarded as an index of size and not of true body length, as it also varies with degree of contraction and variation in body water content. The change in length is, however, less extreme than in nemertean worms. After measurements were completed, all specimens were deep-frozen and stored at $-80^{\circ} \mathrm{C}$ for further tissue analysis

Oxygen consumption and nitrogen excretion. Whole-animal oxygen consumption and nitrogen excretion rates were measured simultaneously $2 \mathrm{~d}$ after collection to minimise the effects of handling stress while still measuring routine metabolic rates as close to field values as possible. Closed-bottle techniques were used. Thirteen to 15 specimens of each species were placed individually in airtight chambers scaled to animal size (using data from preliminary experiments) and left overnight to adjust to experimental conditions. Respiration rates were monitored over an experimental period of up to $12 \mathrm{~h}$, depending on specimen size, using a Fibox-3 fibre optic oxygen 
Table 1. Species sampled and sampling sites

\begin{tabular}{|c|c|c|c|}
\hline Species & $\begin{array}{l}\text { Sampling } \\
\text { site }\end{array}$ & $\begin{array}{l}\text { Depth } \\
(\mathrm{m})\end{array}$ & Substrate \\
\hline $\begin{array}{l}\text { Harpagifer antarcticus, } \\
\text { notothenid fish }\end{array}$ & $\begin{array}{c}\text { East } \\
\text { Beach }\end{array}$ & $5-15$ & $\begin{array}{l}\text { Hard substrate, coastal area } \\
\text { with small to medium rocks } \\
\text { and boulders }\end{array}$ \\
\hline $\begin{array}{l}\text { Ophionotus victoriae, } \\
\text { brittle star }\end{array}$ & $\begin{array}{l}\text { Hangar } \\
\text { Cove }\end{array}$ & $10-20$ & $\begin{array}{l}\text { Soft sediment, inner bay with } \\
\text { sand and mud }\end{array}$ \\
\hline $\begin{array}{l}\text { Parborlasia corrugatus, } \\
\text { nemertean worm }\end{array}$ & $\begin{array}{l}\text { Hangar } \\
\text { Cove }\end{array}$ & $10-20$ & $\begin{array}{l}\text { Soft sediment, inner bay with } \\
\text { sand and mud }\end{array}$ \\
\hline $\begin{array}{l}\text { Doris kerguelenensis, } \\
\text { nudibranch slug }\end{array}$ & $\begin{array}{l}\text { Hangar } \\
\text { Cove }\end{array}$ & $5-15$ & $\begin{array}{l}\text { Hard substrate, shoreline with } \\
\text { big boulders and rocks }\end{array}$ \\
\hline $\begin{array}{l}\text { Paraceradocus miersii, } \\
\text { gammarid amphipod }\end{array}$ & $\begin{array}{l}\text { South } \\
\text { Cove }\end{array}$ & $5-10$ & $\begin{array}{l}\text { Mixed substrate with small } \\
\text { rocks and stones dispersed } \\
\text { on sandy ground }\end{array}$ \\
\hline
\end{tabular}

ifications according to Fraser et al. (2002). In the present study, seawater samples were not deproteinised and sample volume and colour reagent volume were $1.0 \mathrm{ml}$ and $0.5 \mathrm{ml}$, respectively. The assay was calibrated by spiking seawater with known amounts of a urea standard solution. All samples and standards were read with a spectrophotometer at $535 \mathrm{~nm}$. Urea excretion rates are expressed as nmol $\mathrm{CO}\left(\mathrm{NH}_{2}\right)_{2} \mathrm{~h}^{-1} \mathrm{~g}^{-1}$ AFDM.

$\mathrm{O}: \mathrm{N}$ ratios were calculated on an atomic basis. O:N ratios can serve as a metabolic index, providing information about dominance of substrates catabolised. Ratios < 20 indicate mainly

sensor (PreSens). The oxygen content was not allowed to drop below $80 \%$ of the initial saturation during the experiment. Oxygen consumption was expressed as $\mu \mathrm{mol} \mathrm{O} \mathrm{O}^{-1} \mathrm{~g}^{-1}$ AFDM. At the end of each respirometry measurement, water samples were taken from each chamber for analyses of ammonia and urea content (i.e. nitrogen excretion). Control chambers (blanks not containing animals) were run in parallel and all rates were corrected for 'blank' respiration and background levels of ammonia and urea. At the end of each experiment, whole-animal volume, AWM, and body size of each specimen were determined, except the length of the nemertean worms. Nudibranch total body length was measured after full contraction (see 'Faecal egestion' above). Whole-animal dry mass (DM) was measured after drying to a constant mass at $60^{\circ} \mathrm{C}$, and ash mass (AM) was obtained by incineration in a muffle furnace at $500^{\circ} \mathrm{C}$ for $1000 \mathrm{~min}$. AM was subtracted from DM to gain AFDM.

Whereas all urea samples were frozen and stored at $-80^{\circ} \mathrm{C}$ for later analysis, most ammonia samples were analysed immediately. However, when necessary, water samples for ammonia analysis were also deepfrozen with their $\mathrm{pH}$ adjusted twice, before freezing to $\mathrm{pH}<4.5$ and after defrosting to $\mathrm{pH}>7.0$ (Degobbis 1973, Fraser et al. 2002). Ammonia was assayed with $o-$ phthalaldehyde (OPA) and fluorometry, using the method as described by Holmes et al. (1999) with minor modifications. In the present study, ratios of working reagent (WR) to sample volume ranged between 1:1 and 1:2, compared to 1:4 and 1:0.25 in Holmes et al. (1999). The assay was calibrated by spiking seawater with known amounts of ammonium chloride. All samples and standards were read in a TD700 fluorometer. Ammonia excretion is expressed as nmol $\mathrm{NH}_{3} \mathrm{~h}^{-1} \mathrm{~g}^{-1}$ AFDM.

Urea was analysed using the diacetyl monoxime assay of Rahmatullah \& Boyde (1980) with minor mod- protein utilisation, whereas ratios of 50 to 60 suggest more balanced catabolism of protein, lipid and carbohydrate proportions, and ratios $>100$ indicate a diet dominated by lipids and carbohydrates (Mayzaud \& Conover 1988). Only ammonia-nitrogen was included in calculations of $\mathrm{O}: \mathrm{N}$ ratios and while this is likely to underestimate total nitrogen excretion, since other products such as urea, primary amines and uric acid all contribute to nitrogenous waste, it is an accurate enough estimate when serving as a metabolic index. Ammonia is the main (protein-derived) excretory product in marine fish and cold-water invertebrates (Wood 1993, Clarke et al. 1994). Several studies suggest that the ornithine cycle (which is the main pathway of ureagenesis in vertebrates during protein metabolism) is absent in invertebrates (Nicol 1967, Atkinson 1992). Thus, in invertebrates, excreted urea is likely to be derived from deamination of arginine and/or excretion of purines and pyrimidines, suggesting RNA and nucleic acid breakdown rather than protein metabolism (Baldwin 1967, Fraser et al. 2002).

Seasons. Summer was defined as ranging from November to May and winter from June to October (see shaded area in Figs. 2-5), ranges that were determined from long-term oceanographic monitoring (phytoplankton standing stock) (see Clarke et al. 2008) and comparability with other seasonal studies from the same area (e.g. Brockington \& Peck 2001, Fraser et al. 2002, Grange et al. 2004). In Ryder Bay the onset of summer is marked by the phytoplankton bloom, which usually starts in November when chlorophyll a levels exceed $1 \mathrm{mg} \mathrm{m}^{-3}$ for the first time (Clarke et al. 2008). Peak summer values typically exceed $20 \mathrm{mg} \mathrm{m}^{-3}$, whereas winter chlorophyll a values range below $0.2 \mathrm{mg} \mathrm{m}^{-3}$. The end of summer and onset of winter in Ryder Bay is less easily definable and one could argue whether to include May as a summer or winter month. Sedimentation of the plankton bloom can continue 
well into May, thus providing a considerable food source for benthic primary and opportunistic secondary consumers such as brittle stars (Grange et al. 2004). However, Brockington \& Peck (2001) measured non-feeding periods based on gut-content analysis in Antarctic sea urchins from Rothera as lasting from May to December and May to September in 2 consecutive years.

Data analysis. Statistical analysis was carried out using Minitab version 15.1 with a threshold for significance at $p=0.05$. We followed 2 approaches: First, individual data sets were analysed for a significant seasonal difference (ssd) between summer and winter (see definition in 'Seasons' above) using 1-way ANOVA followed by a post hoc Tukey's multiple comparison test on normally distributed data (Ryan-Joiner test). If data could not be transformed using log and square root to gain normal distribution, the non-parametric Kruskal-Wallis test was used to test for seasonal differences. These individual data sets comprise monthly data for each parameter (faecal egestion, oxygen consumption, ammonia excretion, urea excretion, $\mathrm{O}: \mathrm{N}$ ratio) within each species and are presented as mean $\pm \mathrm{SD}$, unless indicated differently, in multi-panel plots.

Second, pooled data sets were used to test how consistent the seasonal patterns were for different parameters within each species, and whether there were differences in seasonality between species. For this purpose, all data for each parameter (faecal egestion, oxygen consumption, ammonia excretion, urea excretion, O:N ratio) were standardised for each species to gain an overall mean of 0 and SD of 1 . This was done by calculating the overall mean for each parameter, for each species, subtracting this mean from each individual value and dividing this result by the SD. We applied a fully factorial general linear model (GLM) to the unbalanced data using sequential sums of squares, testing for significant effects of the 3 fixed factors: parameter, season and species. As the type of prey eaten (higher or lower protein) will affect the quantities of ammonia produced, and the subsequent O:N ratio, either of these 2 parameters could increase or decrease as feeding condition improves. The GLM was therefore re-run without (1) the O:N ratio and (2) the $\mathrm{O}: \mathrm{N}$ ratio, ammonia and also urea (for consistency, as both ammonia and urea make up total nitrogen excretion), to see if the seasonal pattern was still the same across species and parameters.

Third, a literature search was conducted for the most commonly available parameter (seasonal differences in oxygen consumption of Antarctic marine ectotherms) to test if there were differences in seasonality between primary and secondary consumers. Seasonal differences were assessed by comparing factorial scopes, the seasonal multiplicative factor for each parameter between winter and summer. This factorial rise is controlled by changes in temperature and/or nutritional status (Peck 1998). Species in the literature were classified as either 'herbivores' (primary consumers) or predators/scavengers (secondary consumers), except the omnivorous sea urchin Sterechinus neumayeri, which falls in between these groups, relying for up to $50 \%$ of its nutrition on planktonic and benthic algae. Two-sample $t$-tests were run to compare the factorial scopes of herbivore and carnivore species (with and without $S$. neumayeri). The difference in variance in factorial rise between primary and secondary consumers was tested with a Levene's test of homogeneity of variance.

\section{RESULTS}

\section{Faecal egestion}

The ease of collecting faeces varied between species. Parborlasia corrugatus produces external sticky mucus, which made it difficult to separate the faeces. This may have resulted in an underestimation when faecal production was low, especially in winter months. The faeces of Doris kerguelenensis on the other hand were bright orange and easily distinguishable when fresh. However, these disintegrated quickly into a less defined mass that was difficult to collect entirely.

The wet mass of the specimens investigated for faecal egestion did not differ significantly between seasons in any of the 5 species. Faecal egestion was therefore not mass-corrected for a standard animal but expressed per AWM. Though sample size was small (n =6) and individual variability high in all species, none ceased feeding completely during winter (Fig. 2A-E). All species included specimens, however, that did not produce faeces within the first $48 \mathrm{~h}$ after collection. When notothenid fish and nudibranchs were monitored for an additional third day during winter months, all specimens had produced faeces within $72 \mathrm{~h}$ (not included in graphs). Harpagifer antarcticus and Ophionotus victoriae both had their highest and lowest faecal egestion during the overall winter period (Fig. 2A,B). Because of this, faecal egestion (and hence feeding activity) of both species did not differ significantly between winter and summer seasons. Mean maximum rates were $1.30 \pm 1.45 \mathrm{mg} \mathrm{g}^{-1} \mathrm{~d}^{-1}$ (fish) and $1.69 \pm 0.91 \mathrm{mg} \mathrm{g}^{-1} \mathrm{~d}^{-1}$ (brittle star). Parborlasia corrugatus also had no significant seasonal variation in faecal production but the mean maximum value of $0.28 \pm$ $0.14 \mathrm{mg} \mathrm{g}^{-1} \mathrm{~d}^{-1}$ in mid-summer (February 2008) was higher than faecal production in all other months. Fae- 


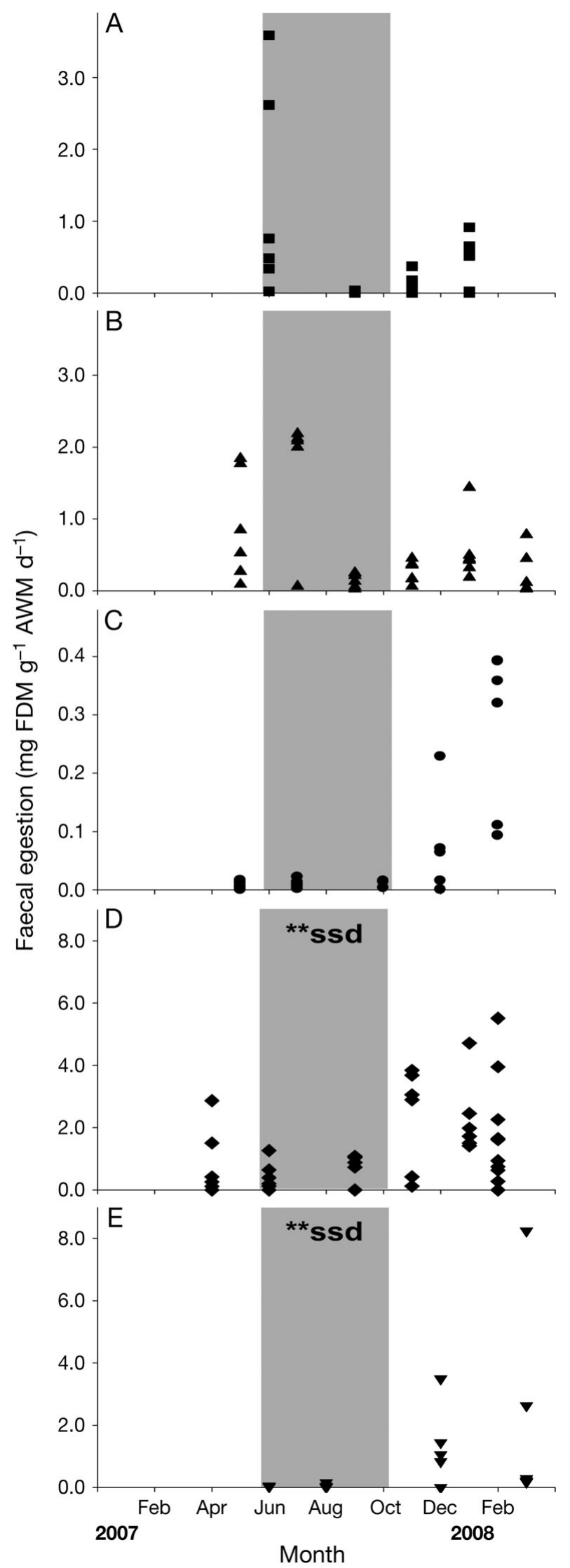

cal production in Parborlasia corrugatus was low compared to other species, and relatively stable throughout the rest of the year (Fig. 2C). In contrast, differences between seasons were significant in Paraceradocus miersii (ANOVA: $F=6.32, \mathrm{p}=0.016$ ) and Doris kerguelenensis (Kruskal-Wallis: $H=10.23, \mathrm{p}=$ 0.001). In both species faecal egestion rates were higher in summer than in winter (Fig. 2D,E), with mean maxima of $2.30 \pm 1.24 \mathrm{mg} \mathrm{g}^{-1} \mathrm{~d}^{-1}$ (amphipod) and $2.31 \pm 3.48 \mathrm{mg} \mathrm{g}^{-1} \mathrm{~d}^{-1}$ (nudibranch) faeces produced.

\section{Oxygen consumption and nitrogen excretion}

AFDM did not differ significantly between summer and winter season in any of the species investigated, and therefore respiration and excretion rates were not masscorrected for a standard animal. Harpagifer antarcticus had the highest mean oxygen consumption of all investigated species, with a maximum value of $10.14 \pm$ $1.97 \mu \mathrm{mol} \mathrm{O} \mathrm{O}^{-1} \mathrm{~g}^{-1}$ AFDM recorded in February, but did not exhibit a significant seasonal pattern (Fig. 3A). Ophionotus victoriae in contrast did have a significant seasonal difference between summer and winter oxygen consumption (ANOVA: $F=21.04, \mathrm{p}<0.001$, Fig. 3B). Its mean summer maximum rate $\left(4.00 \pm 0.84 \mu \mathrm{mol} \mathrm{O}_{2} \mathrm{~h}^{-1} \mathrm{~g}^{-1}\right.$ AFDM) was twice the mean winter minimum value (1.95 $\pm 0.53 \mu \mathrm{mol} \mathrm{O} \mathrm{h}^{-1} \mathrm{~g}^{-1}$ AFDM). The lowest rates were recorded in Parborlasia corrugatus, with a mean minimum in October of $0.74 \pm 0.36 \mu \mathrm{mol} \mathrm{O}_{2} \mathrm{~h}^{-1} \mathrm{~g}^{-1}$ AFDM (Fig. 3C). Neither Parborlasia corrugatus nor Paraceradocus miersii (Fig. 3D) exhibited significant seasonal differences, unlike the fifth species, Doris kerguelenensis, which did show a significant seasonal difference between mean summer and winter oxygen consumption (ANOVA: $F=7.53, \mathrm{p}=0.008$; Fig. 3E). The pattern, however, was less clear than that for $O$. victoriae, and mainly caused by a higher rate in the first summer $\left(3.82 \pm 0.77 \mu \mathrm{mol} \mathrm{O} \mathrm{h}^{-1} \mathrm{~g}^{-1}\right.$ AFDM).

The annual maximal factorial change in oxygen consumption (i.e. difference between mean minimum and mean maximum oxygen consumption) was highest in Ophionotus victoriae at 2.1, compared to 1.7 in Parborlasia corrugatus, 1.6 in Paraceradocus miersii and 1.5 in Harpagifer antarcticus. Doris kerguelenensis showed

Fig. 2. Seasonal faecal egestion of (A) Harpagifer antarcticus (घ), (B) Ophionotus victoriae (A), (C) Parborlasia corrugatus $(\bullet)$, (D) Paraceradocus miersii ( $\bullet$ ) and (E) Doris kerguelenensis $(\boldsymbol{\nabla})$. Data are shown as individual values for each month. Shaded area represents the winter season (June to October 2007); summer seasons are February to May 2007 and November 2007 to March 2008. ${ }^{* *}$ ssd indicates significant seasonal difference between summer and winter: (D) ANOVA: $F=6.32, \mathrm{p}=0.016$; (E) Kruskal-Wallis: $H=10.23, \mathrm{p}=0.001$. FDM: faeces dry mass; AWM: animal wet mass 


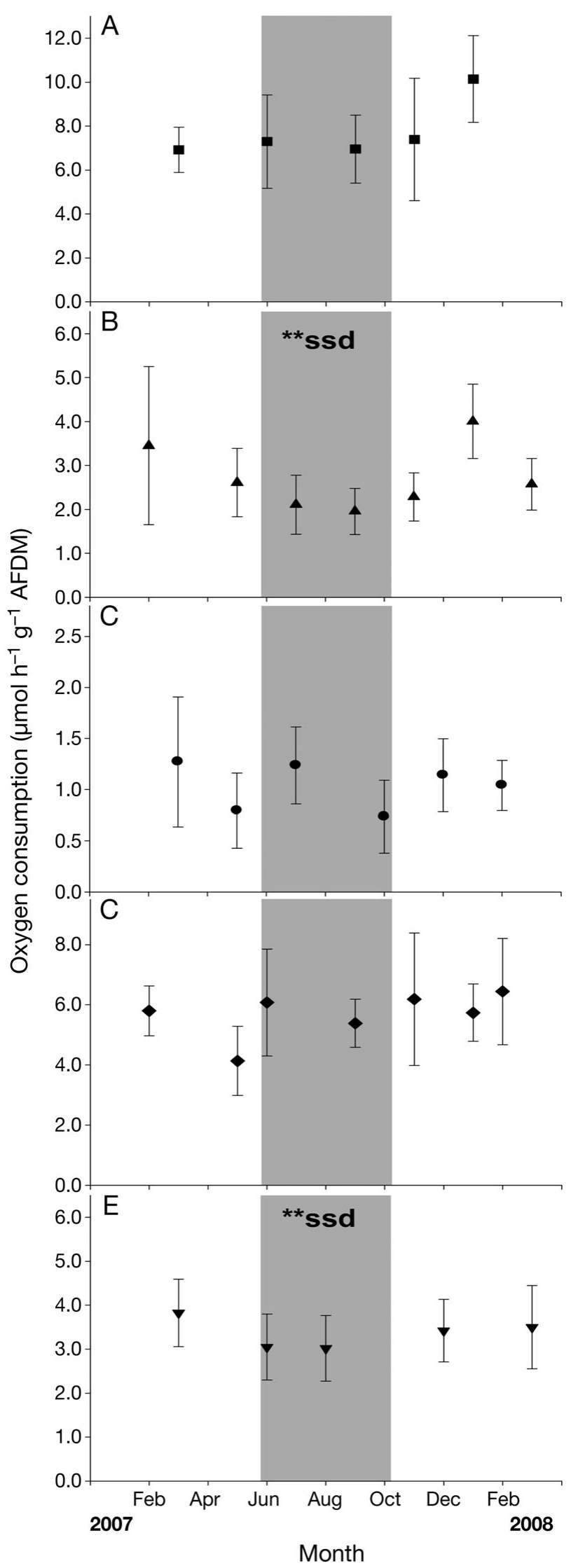

the smallest annual maximal factorial change of 1.3. In 4 out of the 5 investigated species (not Paraceradocus miersii), the lowest rates were recorded in the winter and the highest rates in the summer seasons.

Mean ammonia excretion rates of the 5 study species are depicted in Fig. 4A-E (closed symbols, left $y$-axis). Harpagifer antarcticus had significantly higher ammonia excretion in winter than in summer (ANOVA: $F=22.63, \mathrm{p}<0.001$ ) and also the highest mean ammonia excretion level (651 $\pm 261.79 \mathrm{nmol}$ $\mathrm{NH}_{3} \mathrm{~h}^{-1} \mathrm{~g}^{-1}$ AFDM) of all species recorded (Fig. 4A). This seasonal pattern was reversed in Ophionotus victoriae (Fig. 4B), exhibiting higher ammonia excretion in summer compared to winter (Kruskal-Wallis: $H=$ 28.44, $\mathrm{p}<0.001$ ), thus mirroring the significant seasonal pattern in respiration. Summer rates peaked at a mean maximum of $295.86 \pm 197.23 \mathrm{nmol} \mathrm{NH}_{3} \mathrm{~h}^{-1} \mathrm{~g}^{-1}$ AFDM, 16.2 times the mean winter minimum excretion rate $\left(18.29 \pm 14.78 \mathrm{nmol} \mathrm{h}^{-1} \mathrm{~g}^{-1}\right.$ AFDM) within this species. Parborlasia corrugatus (Fig. 4C), Paraceradocus miersii (Fig. 4D) and Doris kerguelenensis (Fig. 4E) showed little variation in ammonia excretion through the year, without significant seasonal differences. Factorial changes were generally $<2.7$.

Mean urea excretion showed high individual variability throughout the year in all species (Fig. 4A-E, open symbols, right $y$-axis). Only Parborlasia corrugatus exhibited a weak seasonal difference (KruskalWallis: $H=4.12, \mathrm{p}=0.042$ ) with winter values being significantly higher than summer rates (Fig. 4C). However, all the values for Parborlasia corrugatus were very low and close to the detection limit of the assay (means ranging from 4 to $8 \mathrm{nmol} \mathrm{CO}\left(\mathrm{NH}_{2}\right)_{2} \mathrm{~h}^{-1} \mathrm{~g}^{-1}$ AFDM). The other species, Harpagifer antarcticus, Ophionotus victoriae, Paraceradocus miersii and Doris kerguelenensis, had slightly higher mean urea excretion rates, ranging between 10 and $40 \mathrm{nmol} \mathrm{CO}\left(\mathrm{NH}_{2}\right)_{2}$ $\mathrm{h}^{-1} \mathrm{~g}^{-1}$ AFDM.

\section{$\mathrm{O}: \mathrm{N}$ ratios}

There was no consistent pattern in O:N ratios across species; however, there were significant differences between seasons in all except Paraceradocus miersii (Fig. 5A-E). O:N ratios in Harpagifer antarcticus, Ophionotus victoriae and Paraceradocus miersii were

Fig. 3. Seasonal oxygen consumption of (A) Harpagifer antarcticus ( $\square$ ), (B) Ophionotus victoriae (\), (C) Parborlasia corrugatus (๑), (D) Paraceradocus miersii ( $\bullet$ ) and (E) Doris kerguelenensis $(\boldsymbol{\nabla})$. Data are shown as mean \pm SD. Shaded area represents the winter season (see Fig. 2 legend). ${ }^{* *}$ ssd indicates significant seasonal difference between summer and winter: (B) ANOVA: $F=21.04, p<0.001$; (E) ANOVA: $F=$ 7.53, $\mathrm{p}=0.008$. AFDM: ash-free dry mass 


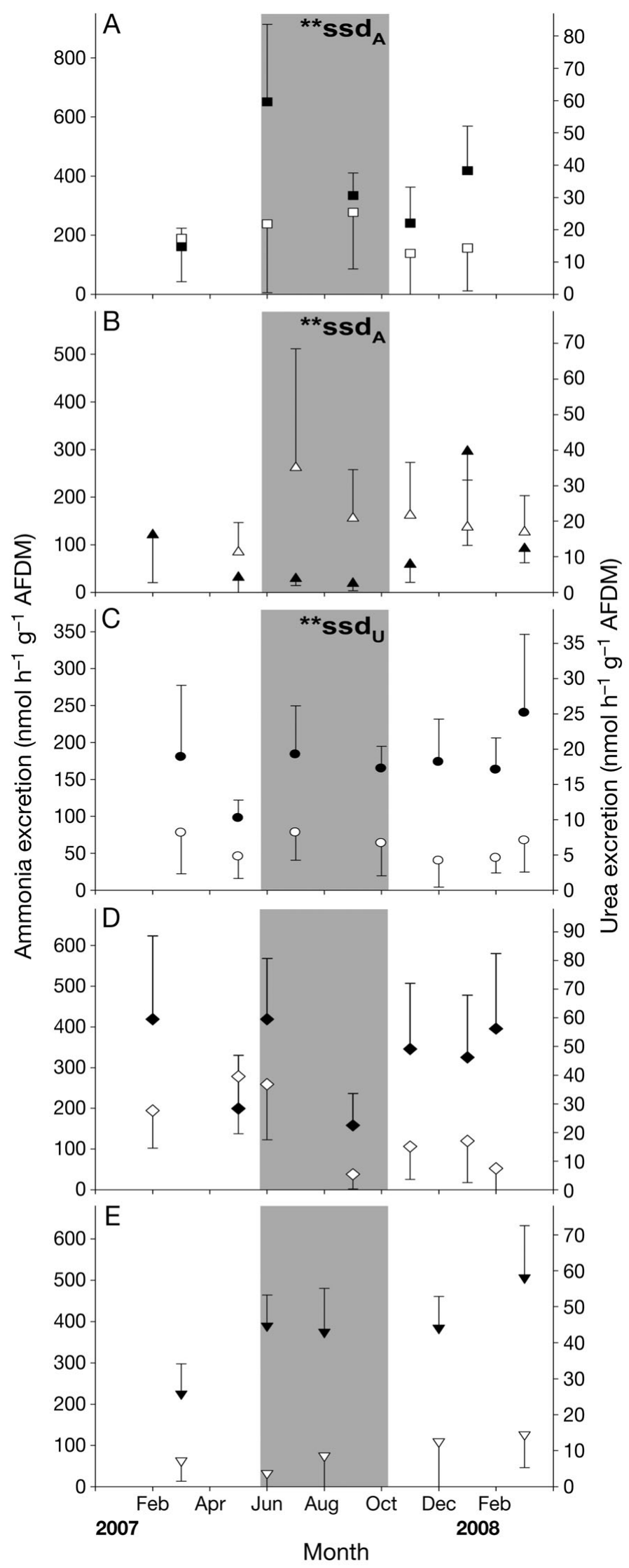

higher (generally > 24) than in Parborlasia corrugatus and Doris kerguelenensis, with a mean maximum ratio of $231.50 \pm 166.54$ in $O$. victoriae. O:N ratios in $H$. antarcticus (Fig. 5A) were significantly lower in winter $(24.37 \pm 5.29$; ANOVA: $F=25.51, \mathrm{p}<0.001)$ than in summer, while the opposite was the case in $O$. victoriae (Fig. 5B), with significantly lower ratios in the second summer season $(29.77 \pm 11.80$; ANOVA: $F=19.26, \mathrm{p}<$ 0.001). Parborlasia corrugatus had the lowest O:N ratios of all investigated animals, with mean values ranging between $8.97 \pm 3.74$ and $17.77 \pm 7.07$ (Fig. 5C). Summer and winter ratios were significantly different, reaching a significant minimum in late winter (Kruskal-Wallis: $H=6.85, \mathrm{p}=0.009$ ). O:N ratios in Paraceradocus miersii were relatively stable throughout the year $(30.16 \pm$ 14.09 to $48.94 \pm 27.93$ ), without significant seasonal differences (Fig. 5D). Mean values for D. kerguelenensis ranged between $14.62 \pm 3.39$ and $17.44 \pm 3.41$ in most months of the year, except a significantly higher mean O:N ratio of $34.01 \pm 10.30$ recorded in March 2007 (Fig. 5E). The resulting significant seasonal difference (ANOVA: $F=6.01, \mathrm{p}=0.017$ ) was mainly driven by this first summer, which had an O:N ratio twice as high as in the winter. Overall, changes in O:N ratios were species-specific and driven either by changes in oxygen consumption (Parborlasia corrugatus), ammonia excretion ( $H$. antarcticus, Paraceradocus miersii, $D$. kerguelenensis) or both (O. victoriae).

$\mathrm{O}: \mathrm{N}$ ratios may be used to elucidate which substrate fuels the metabolic activities. Only the low O:N ratios in Parborlasia corrugatus (8 to 17) and Doris kerguelenensis (14 to 17) indicated utilisation of mainly protein. All other species had higher ratios (24 to 91 in Harpagifer antarcticus, 29 to 231 in Ophionotus victoriae, 30 to 62 in Paraceradocus miersii), suggesting mixed utilisation, or a high percentage of lipids and carbohydrates $(\geq 50 \%)$ being used to fuel metabolic needs.

\section{Consistency of seasonal patterns}

When seasonal comparisons were run on all 5 parameters, on 4 parameters (excluding O:N ratio) or 2 parameters (also excluding ammonia and urea), there

Fig. 4. Seasonal ammonia excretion $(\boldsymbol{\square}, \boldsymbol{\Delta}, \bullet, \bullet, \boldsymbol{\nabla})$ and urea excretion $(\square, \Delta, \bigcirc, \diamond, \nabla)$ of (A) Harpagifer antarcticus, (B) Ophionotus victoriae, (C) Parborlasia corrugatus, (D) Paraceradocus miersii and (E) Doris kerguelenensis. Data are shown as mean $\pm \mathrm{SD}$. Shaded area represents the winter season (see Fig. 2 legend). ${ }^{* *} \operatorname{ssd}_{\mathrm{A}}$ indicates significant seasonal difference in ammonia excretion between summer and winter: (A) ANOVA: $F=22.63, \mathrm{p}<0.001$; (B) Kruskal-Wallis: $H=28.44$, $\mathrm{p}<0.001 .{ }^{* *} \mathrm{ssd}_{\mathrm{U}}$ indicates significant seasonal difference in urea excretion between summer and winter: (C) KruskalWallis: $H=4.21, \mathrm{p}=0.042$. AFDM: ash-free dry mass 


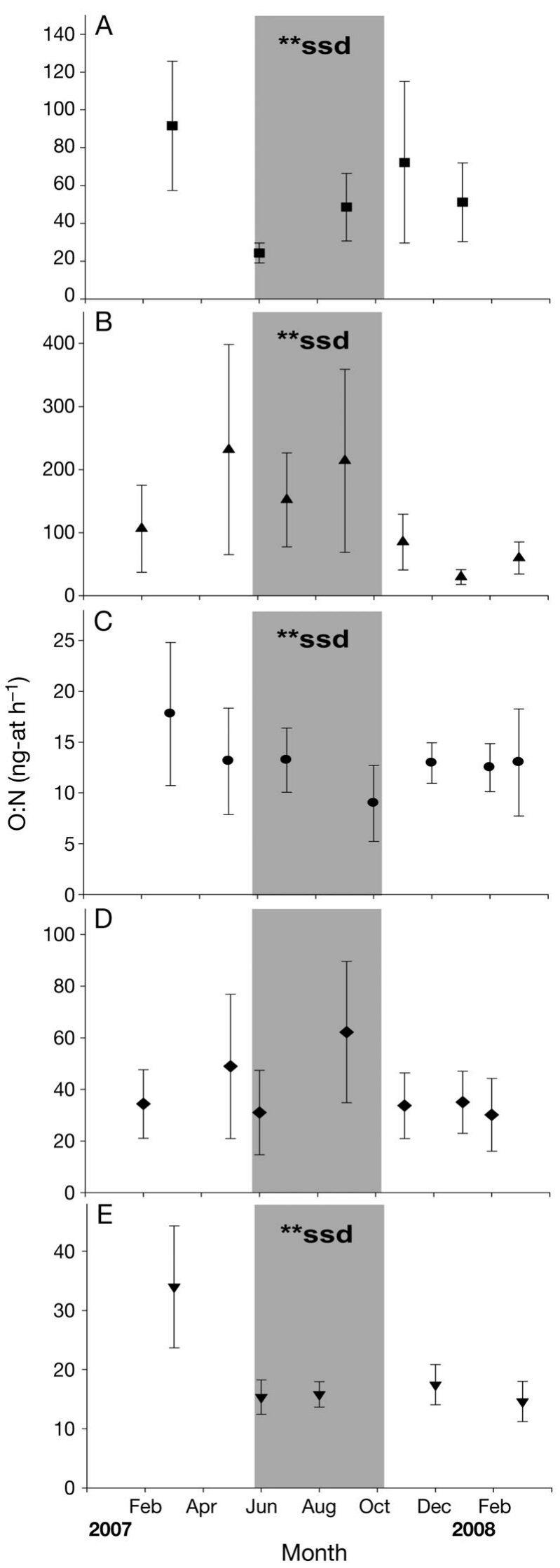

was still a significant effect of the 3-way interaction, indicating that parameters varied differently between seasons and this relationship was different for different species. The comparison including all 5 parameters was therefore used for further analysis. Within each species the data for each parameter was standardised to a mean of 0 and a SD of 1 to allow comparison of the seasonal variation in parameters within and between species (summer vs. winter; Table 2). Season had a significant overall effect $(F=5.5, \mathrm{p}=0.019)$ but there were also significant affects of the 2-way interactions: parameter $\times$ season $(F=5.2, \mathrm{p}<0.001)$, season $\times$ species $(F=$ $2.7, \mathrm{p}=0.029)$; and the 3-way interaction parameter $\times$ season $\times$ species $(F=5.2, \mathrm{p}<0.001)$. The 2 -way and 3 -way interactions indicate that parameters and species responded in a non-consistent way to season.

The literature search and data presented in the present paper allowed the seasonal factorial increase in oxygen consumption between winter and summer to be compared between primary and secondary consumers (Fig. 6, Table 3). None of the 2-sample $t$-tests run for different combinations of the herbivore, omnivore and carnivore species yielded any significant differences between the seasonal factorial rise in oxygen consumption in 'herbivores' and that in carnivores (predators/scavengers) (Table 3: Comparisons 1 to 3). Two Levene's tests for equal variance (homogeneity of variance) on the other hand revealed significant differences between 'herbivores' (with omnivorous Sterechinus neumayeri) and carnivores, as well as between 'herbivores' and carnivores (both without $S$. neumayeri) (Table 3: Comparisons 1 and 3). The variance in seasonal factorial rise in oxygen consumption was significantly smaller in predators/scavengers $\left(\sigma^{2}=0.105\right)$ than in 'herbivores' $\left(\sigma^{2}=0.860\right.$ and $\left.\sigma^{2}=1.026\right)$. This shows that secondary consumers are more homogenous in one of their metabolic activities (oxygen consumption) throughout the year than primary consumers.

\section{DISCUSSION}

Antarctic shallow-water habitats are characterised by, amongst other things, marked seasonal environmental variations. The predator and scavenger assem-

Fig. 5. Seasonal O:N ratios of (A) Harpagifer antarcticus (घ),

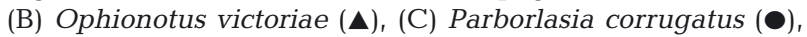
(D) Paraceradocus miersii ( $\bullet$ ) and (E) Doris kerguelenensis $(\boldsymbol{\nabla})$. Data are shown as mean \pm SD. Shaded area represents the winter season (see Fig. 2 legend). ${ }^{* *}$ ssd indicates significant seasonal difference between summer and winter: (A) ANOVA: $F=25.51, \mathrm{p}<0.001$; (B) ANOVA: $F=19.26, \mathrm{p}<$ 0.001; (C) Kruskal-Wallis: $H=6.85, \mathrm{p}=0.009$; (E) ANOVA: $F=6.01, \mathrm{p}=0.017$ 
Table 2. Summary of results from formal hypothesis testing. Output of general linear model $(G L M ; p=0.05)$ is given for differences between the effect of fixed factors and differences in the effect of an interaction between fixed factors. Fixed factors used were firstly Parameter (5 levels: faecal egestion, oxygen consumption, ammonia excretion, urea excretion, O:N ratio); secondly Season (2 levels: winter, summer); and thirdly Species (5 levels: Harpagifer antarcticus, Ophionotus victoriae, Parborlasia corrugatus, Paraceradocus miersii, Doris kerguelenensis). Seq SS = sequential sums of squares. Significant results are in bold

\begin{tabular}{|lcrrr|}
\hline Source & df & Seq SS & $F$ & \multicolumn{1}{c|}{$\mathrm{p}$} \\
\hline Parameter & 4 & 0.852 & 0.19 & 0.943 \\
Season & 1 & 6.186 & 5.54 & $\mathbf{0 . 0 1 9}$ \\
Species & 4 & 0.590 & 0.13 & 0.971 \\
Parameter $\times$ Season & 4 & 23.053 & 5.16 & $<\mathbf{0 . 0 0 1}$ \\
Parameter $\times$ Species & 16 & 2.605 & 0.15 & 1.000 \\
Season $\times$ Species & 4 & 12.085 & 2.70 & $\mathbf{0 . 0 2 9}$ \\
Parameter $\times$ Season & 16 & 92.695 & 5.19 & $<\mathbf{0 . 0 0 1}$ \\
$\quad \times$ Species & & & & \\
Error & 1759 & 1964.785 & & \\
Total & 1808 & 2102.852 & & \\
\hline
\end{tabular}

blages of the shallows often encompass the most abundant large animals, including many mobile generalists (Aronson et al. 2007). While the seasonality of many primary consumers has been studied in detail in Antarctic waters (e.g. Barnes \& Clarke 1995), yearround predator and scavenger ecophysiology is less well known. In contrast to expectations, Antarctic secondary consumers studied here showed varying degrees of seasonality in their feeding and metabolic energy utilisation. Strategies ranged from seasonal to even, with 3 out of the 5 species (Harpagifer antarcti-

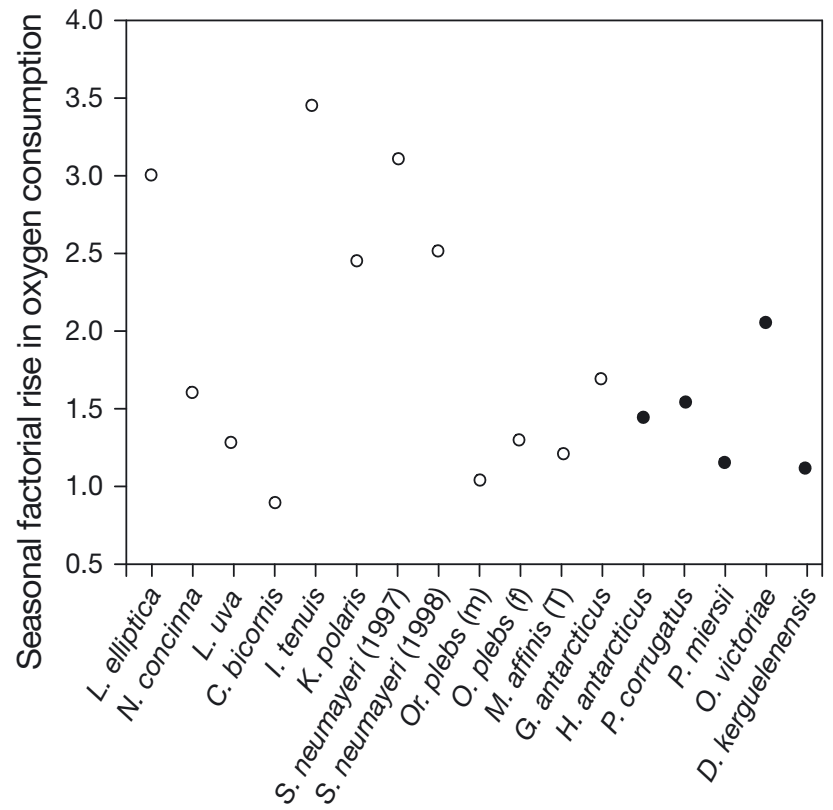

Fig. 6. Comparison of seasonal factorial rise in oxygen consumption from winter to summer in a range of polar and 1 cold temperate (T) marine species. Modified from Barnes \& Peck (2005). Open circles represent data from previous studies: Brockington (2001, Laternula elliptica), Fraser et al. (2002, Nacella concinna), Peck et al. (1987, 1997, Liothyrella uva), Barnes \& Peck (2005, Camptoplites bicornis, Isoseculiflustra tenuis, Kymella polaris), Brockington \& Peck (2001, Sterechinus neumayeri), Rakusa-Suszczewski (1982, Orchomene plebs, $\mathrm{m}=$ male, $\mathrm{f}=$ female), Lehtonen (1996, Monoporeia affinis, cold temperate), Janecki \& Rakusa-Suszczewski (2006, Glyptonotus antarcticus). Closed circles represent data from the present study (Harpagifer antarcticus, Parborlasia corrugatus, Paraceradocus miersii, Ophionotus victoriae, Doris kerguelenensis)
Table 3. Summary of statistical test results from comparison of seasonal factorial rise in oxygen consumption from winter to summer in different trophic guilds. Species and data as in Fig. 6. Herbivores: Laternula elliptica ${ }^{1}$, Nacella concinna $^{1}$, Liothyrella uva ${ }^{1}$, Camptoplites bicornis ${ }^{1}$, Isoseculiflustra tenuis ${ }^{1}$, Kymella polaris $^{1}$. Omnivore: Sterechinus neumayeri ${ }^{1}$. Carnivores: Orchomene plebs ${ }^{1}$, Monoporeia affinis ${ }^{1}$, Glyptonotus antarcticus ${ }^{1}$, Harpagifer antarcticus ${ }^{2}$, Parborlasia corrugatus ${ }^{2}$, Paraceradocus miersii ${ }^{2}$, Ophionotus victoriae ${ }^{2}$, Doris kerguelenensis ${ }^{2}\left({ }^{1}\right.$ after Barnes \& Peck 2005, ${ }^{2}$ the present study). Significant results are in bold. $S$. neumayeri is excluded from comparison unless stated otherwise

\begin{tabular}{|c|c|c|c|c|c|c|}
\hline \multirow[t]{2}{*}{ Comparison } & \multirow[t]{2}{*}{ Trophic guilds } & \multirow[t]{2}{*}{$\begin{array}{c}\text { Variance, } \\
\sigma^{2}\end{array}$} & \multicolumn{2}{|c|}{$\begin{array}{c}\text { Levene's test for } \\
\text { equal variance } \\
\text { (homogeneity) }\end{array}$} & \multicolumn{2}{|c|}{$\begin{array}{l}\text { Two-sample } \\
t \text {-test (log- } \\
\text { transformed data) }\end{array}$} \\
\hline & & & $t$ & $\mathrm{p}$ & $t$ & $\mathrm{p}$ \\
\hline 1 & $\begin{array}{l}\text { Herbivores }^{\mathrm{a}} \\
\text { vs. carnivores }\end{array}$ & $\begin{array}{l}0.860 \\
0.105\end{array}$ & 5.98 & 0.027 & 2.26 & 0.050 \\
\hline 2 & $\begin{array}{l}\text { Herbivores } \\
\text { vs. carnivores }\end{array}$ & $\begin{array}{l}1.026 \\
0.423\end{array}$ & 2.88 & 0.110 & 0.82 & 0.441 \\
\hline 3 & $\begin{array}{l}\text { Herbivores } \\
\text { vs. carnivores }\end{array}$ & $\begin{array}{l}1.026 \\
0.105\end{array}$ & 14.45 & 0.002 & 1.43 & 0.203 \\
\hline
\end{tabular}

cus, Ophionotus victoriae and Doris kerguelenensis; see Table 4) exhibiting seasonality in some, but not all, of these characteristics. The greater flexibility in feeding strategies of secondary consumers may reduce some of the fluctuations in feeding, which could partially explain why the variance of oxygen consumption was reduced in secondary consumers compared to primary consumers. However, food quality and quantity may vary through the year and to a certain extent with a seasonal component. For example, the globally high rates of disturbance (reviewed in Barnes \& Conlan 2007), especially mediated by ice scours, cause seasonally predictable windfalls of carrion for such assemblages (see Smale et al. 2008). Other factors, such as the timing of 
Table 4. Harpagifer antarcticus, Ophionotus victoriae, Parborlasia corrugatus, Paraceradocus miersii and Doris kerguelenensis. Summary of seasonal changes in different physiological parameters and emerging strategies. ${ }^{* *}$ ssd: significant seasonal

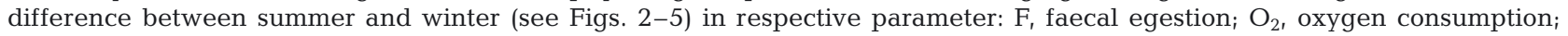
A, ammonia excretion; $\mathrm{U}$, urea excretion; O:N, O:N ratio

\begin{tabular}{|c|c|c|c|c|c|c|c|c|c|}
\hline \multirow[t]{2}{*}{ Species } & \multicolumn{5}{|c|}{ Parameter } & \multicolumn{2}{|c|}{ O:N ratio } & \multirow[t]{2}{*}{ Strategy } & \multirow[t]{2}{*}{ Metabolic substrate } \\
\hline & $\mathrm{F}$ & $\mathrm{O}_{2}$ & $\mathrm{~A}$ & $\mathrm{U}$ & $\mathrm{O}: \mathrm{N}$ & Winter & Summer & & \\
\hline H. antarcticus & & & ${ }^{* *}$ ssd & & ${ }^{* *} \mathrm{ssd}$ & Medium & High & $\begin{array}{l}\text { Mixed- } \\
\text { uncoupled }\end{array}$ & $\begin{array}{l}>50 \% \text { lipids and carbohydrates, } \\
\text { more proteins in winter }\end{array}$ \\
\hline O. victoriae & & ${ }^{* *}$ ssd & ${ }^{* *}$ ssd & & ${ }^{* *}$ ssd & Very high & $\begin{array}{l}\text { Medium to } \\
\text { very high }\end{array}$ & $\begin{array}{l}\text { Mixed- } \\
\text { seasonal }\end{array}$ & $\begin{array}{l}>70 \% \text { lipids and carbohydrates } \\
\text { most of year, rarely proteins } \\
\text { (only in summer) }\end{array}$ \\
\hline $\begin{array}{l}\text { Parborlasia } \\
\text { corrugatus }\end{array}$ & & & & ${ }^{* *}$ ssd & ${ }^{* *}$ ssd & Low & Medium & $\begin{array}{l}\text { Even- } \\
\text { uncoupled }\end{array}$ & $>70 \%$ proteins \\
\hline $\begin{array}{l}\text { Paraceradocus } \\
\text { miersii }\end{array}$ & ${ }^{* *}$ ssd & & & & & High & Medium & $\begin{array}{c}\text { Even- } \\
\left.\text { (seasonal }^{\mathrm{a}}\right)\end{array}$ & $\begin{array}{l}>50 \% \text { lipids and carbohydrates, } \\
\text { occasionally proteins }\end{array}$ \\
\hline D. kerguelenensis & ${ }^{* *}$ ssd & ${ }^{* *}$ ssd & & & ${ }^{* *}$ ssd & Low & $\begin{array}{l}\text { Medium } \\
\text { to high }\end{array}$ & $\begin{array}{l}\text { Mixed- } \\
\text { seasonal }\end{array}$ & $\begin{array}{l}>50 \% \text { proteins, some lipids and } \\
\text { carbohydrates }\end{array}$ \\
\hline
\end{tabular}

reproduction, may impose a seasonal energy requirement on species that is not directly related to the food supply of the adult but to the food requirements of the early life-history stages (Bowden et al. 2009).

Faeces were produced all year round by all study species, although in 3 of the species studied (Harpagifer antarcticus, Parborlasia corrugatus and Doris kerguelenensis), at least one month in winter had mean values close to zero, which suggests that, deviating from our initial hypothesis, food quantity and/or quality is not constant all year round. The dominant result was that rates of faecal egestion and thus feeding activity varied strongly between individuals and species. Our hypothesis of less extreme seasonality in feeding activity in these representatives of Antarctic secondary consumers than primary consumers was rejected. With the exception of Paraceradocus miersii, the other 4 species studied here all included a period of cessation of feeding in some of the analysed specimens that could have been 2 or up to $4 \mathrm{mo}$, similar to the variability found in several suspension feeders (Barnes \& Clarke 1995). There were some strong parallels in intra- and inter-specific variability between these carnivores and scavengers, which reflected the patterns previously found across primary consumers (e.g. Barnes \& Clarke 1994, Peck et al. 2005, 2006). This shows that despite the extreme and seasonal nature of the environment, there is still considerable scope for differing patterns of activity, even within feeding guilds.

As hypothesised there was no consistent seasonal pattern in oxygen consumption and nitrogen excretion in 4 out of the 5 species (Harpagifer antarcticus, Parborlasia corrugatus, Paraceradocus miersii and Doris kerguelenensis; see Table 4). As with most polar ectotherms, oxygen use is low (Clarke \& Johnston 1999, Peck \& Conway 2000) and the ranges in seasonal rise in oxygen consumption reported here fall within the range found across Antarctic primary and secondary consumers (Fig. 6). Generally there is less variability in the seasonal rise (factorial scope) in oxygen consumption in secondary ( 1 to 2 ) than primary (0.9 to $3.5)$ consumers. The $Q_{10}$ temperature coefficient is another measure of the rate of change of a biological or chemical system as a consequence of increasing the temperature by $10^{\circ} \mathrm{C}$ and a useful way to express the temperature-dependence of a process such as the seasonal rise in oxygen consumption. Whole-animal systems generally exhibit $Q_{10}$ values between 2 and 3 for purely temperature-driven effects on normal physiological functions (Clarke 1983, Hochachka 1991). Brockington \& Clarke (2001) calculated $Q_{10}$ of 2.54 and 2.99 for a temperature-driven increase in oxygen consumption from winter to summer in starved specimens of Antarctic sea urchin Sterechinus neumayeri as compared to a theoretical $Q_{10}$ of around 30 for the wild (not starved) population at the same time in the field. Brockington \& Clarke (2001) showed that in S. neumayeri, 15 to $20 \%$ of summer increase in respiration could be explained directly by seasonal temperature rise and 80 to $85 \%$ by feeding, growth and reproduction. Morley et al. (2007) also showed that the $Q_{10}$ increase in metabolic rate of the infaunal bivalve Laternula elliptica could largely be explained by differences in seasonal feeding activity and the associated metabolic suppression in winter. Both these studies demonstrated that field temperature was only a minor factor influencing the seasonal difference in respiration and that seasonal activity was more important. Calculated $Q_{10}$ values in the present study ranged 
between 4.9 and 241.4, which is clearly outside the normal scope for temperature-driven processes, thus confirming the importance of feeding and other activities contributing to the seasonal rise in metabolic rates.

Seasonality was however apparent, and our hypothesis was rejected in all species but Paraceradocus miersii in terms of O:N ratios (see Table 2). O:N ratios vary from $<20$, pure protein, to $>50-100$, representing a more lipid- and carbohydrate-based diet (Mayzaud \& Conover 1988). The ratio depends only in part on the elemental composition of the food ingested by an animal or of the animal itself. Internal energy requirements and nutritional status (fed/starved) as well as other factors such as seasonal changes in life cycles and food quality may also influence O:N ratios. Previous investigations of metabolic substrates using analysis of O:N ratios in Antarctic marine ectotherms have generally found low values, predominantly <30 (e.g. Clarke \& Prothero-Thomas 1997, Peck et al. 1997, Robertson et al. 2001, Fraser et al. 2002). These studies included work on carnivores, and led to the hypothesis that life at low temperatures allowed low rates of energy utilisation, and hence the fuelling of metabolism using protein as the main substrate (Peck 1998). The present results, however, indicate a far wider use of metabolic substrate across the carnivore/scavenger trophic guild than previously identified. The metabolic substrates varied differently between seasons depending on whether the species concerned utilised more protein or lipids and carbohydrates to support metabolic requirements.

Despite the fact that we only investigated 5 species, we found a remarkable degree of diversity in physiological strategies and to our knowledge this is the first study to show such variety in polar benthic secondary consumers. The diversity in seasonal strategies within one trophic guild in this near-shore polar environment is comparable to some temperate and tropical regions (see Coma et al. 2000, Hanamura et al. 2008). Although they live in similar biogeographic ranges, depths and habitats, the variability of strategies of the present study species suggests that a species-byspecies approach should be taken to examine the key underlying patterns and drivers as well as assessing generalities.

\section{Harpagifer antarcticus}

These small notothenid fish have been reported to feed all year round (Daniels 1978), but as food is patchy in time and space, Harpagifer antarcticus likely encounter phases with little or no food available. We consider it likely that at least some of the specimens sampled for the present study had gone through such a period. $H$. antarcticus may also increase feeding and activity before commencing nest preparation and spawning at the start of winter (Daniels 1978, 1979). A difference between males and females would also explain the higher variability in feeding and ammonia excretion in June.

The small increase in temperature between winter and summer $\left(-1.2\right.$ to $\left.0.8^{\circ} \mathrm{C}\right)$ could also only partially have driven the rise in Harpagifer antarcticus' oxygen consumption between mean winter minimum and mean summer maximum $\left(Q_{10}\right.$ of 4.9$)$. Clarke \& Johnston (1999) reported $Q_{10}$ ranging from 1.83 to 2.40 for a broad range of teleost fish metabolism across latitudes. Increased activity by $H$. antarcticus in the summer could account for the extra increase in metabolism recorded in the present study. Our value for the factorial scope, of 1.5 , lies within the range of 1.3 to 1.6 reported for factorial aerobic scope for another polar fish, Arctic cod Boreogadus saida (Hop \& Graham 1995).

Mean values for routine ammonia excretion in Harpagifer antarcticus ranged from 170 to $650 \mathrm{nmol} \mathrm{NH}$ $\mathrm{h}^{-1} \mathrm{~g}^{-1}$ AFDM, which agrees with the previously reported range covering laboratory-starved and recently fed individuals (Boyce \& Clarke 1997, Boyce 1999). Urea excretion accounted for approximately 10 to $20 \%$ of total nitrogen excreted, as was also found by Boyce (1999). Excretion rates for both ammonia and urea are 2 to 10 times lower than values reported for temperate and tropical species (Brett \& Zala 1975, Jobling 1994), which is in line with relationships of fish metabolic rate across latitudes (Clarke \& Johnston 1999).

Changes in ammonia excretion drove changes in $\mathrm{O}: \mathrm{N}$ ratios and lead to the significant seasonal difference (24 to 91), with lower values in winter than in summer. In June, the month with the lowest (significant) O:N ratio, at the start of the spawning season, Harpagifer antarcticus exhibited both its highest ammonia excretion and faecal egestion. This could be due to increased feeding before commencing nest building and spawning, which has been shown to affect O:N ratios in $H$. antarcticus. O:N ratios of $H$. antarcticus range from 5 to 6 in well-fed fish (satiation) to $>100$ in fish on low rations (Boyce \& Clarke 1997). In regularly fed $H$. antarcticus, O:N ratios are $20 \pm 5$ (e.g. Jobling 1994), indicating that protein and lipids (and carbohydrates) are more equally used, protein being roughly $50 \%$ of catabolised substrates.

In summary, the carnivore Harpagifer antarcticus exhibits a mixture of seasonal strategies with some significant seasonal differences. However, it does not have a clear and consistent seasonal pattern across physiological parameters. Key influences are likely to be reproductive activity and food availability. 


\section{Ophionotus victoriae}

Ophionotus victoriae is an opportunistic generalist with great fluctuation of food types between locations, times of year, and between years, depending on the strength of the sedimentation of phyto-detritus (Grange et al. 2004); strategies range from active predator, cannibal, scavenger to detritivore (Fratt \& Dearborn 1984, Dahm 1996, Smale et al. 2007). Although there was a slight trend towards increased feeding in January, the signal was not significant and the faecal egestion peak was seasonally uncoupled from respiration peaks. Fecundity and nutritional condition in $O$. victoriae indicate that gonad and gut index are related to downward flux of material (phyto- and other detritus) into the benthos from the previous summer bloom (Grange et al. 2004). 2006 was a year of high primary productivity and therefore sedimentation at this site (Clarke et al. 2008).

The importance of primary production to the food supply may explain why Ophionotus victoriae was the only investigated species to show a significant seasonal pattern in metabolic rates similar to that seen in many Antarctic suspension feeders, with a summer high and winter low (Brockington 2001, Brockington \& Peck 2001), although not all Antarctic primary consumers studied exhibit strong seasonality of metabolism (Peck et al. 1987, Fraser et al. 2002). However, the lack of a significant signal in faecal egestion does not support differences in feeding as the cause of these brief summer peaks in oxygen consumption and ammonia excretion, suggesting that changes in temperature, food quality, growth or reproduction could be more important. This would be supported by the very large interannual variations in reproductive output reported previously for this species (Grange et al. 2004).

Seasonal changes in $\mathrm{O}: \mathrm{N}$ ratios in Ophionotus victoriae were driven by both changes in oxygen consumption and ammonia excretion. However, there are probably other influences overlaying the seasonality as the $\mathrm{O}: \mathrm{N}$ pattern was notably different from that for oxygen consumption and ammonia excretion, which followed the general seasonality of summer maxima and winter minima. O:N ratios were very variable but did not have a significant seasonal signal during the year, and this may have been due to diet quality or metabolic factors. In January 2008 ammonia excretion rose 16-fold whereas oxygen consumption increased only 2-fold, resulting in very low O:N ratios. Interestingly, wild Sterechinus neumayeri also exhibited a significant decrease in O:N ratios from around 20 in winter to $<10$ in summer, illustrating a switch from a lipid/carbohydrate-protein balanced diet to a greater dependence on protein as the main metabolic substrate (Brocking- ton \& Clarke 2001). In the present study, O. victoriae relied on a high percentage $(>50 \%)$ of lipids and carbohydrates as metabolic fuel for most of the year and switched to a more lipid/carbohydrate-protein balanced metabolic substrate during a short summer period. Even though there was no signal in faecal egestion indicating increased feeding activity in summer, the significantly lower $\mathrm{O}: \mathrm{N}$ ratios may indicate different or better quality food with a higher protein content available in summer compared to winter. In addition, high oxygen consumption and ammonia excretion may indicate changed energy demand and metabolic substrates due to reproductive activity. $O$. victoriae typically spawn at the start of summer (Grange et al. 2004) but $O$. victoriae in the present study spawned in January 2008, coinciding with the peaks in oxygen consumption and ammonia excretion.

In summary, Ophionotus victoriae exhibits a mixture of strategies, with significant seasonal patterns in most of its physiological processes. These were, however, only clear and consistent in respiration and nitrogen excretion. Key influences are likely to be reproductive activity and changing food type and quality. O. victoriae appears more coupled to environmental seasonality in common with Antarctic 'herbivores'; however, its nutritional plasticity may provide advantages in flexibility compared to suspension feeders. The relative importance of nutritional and metabolic flexibility may vary between taxa and trophic groups in Antarctica (Peck \& Barnes 2004), and there is currently too little information to be conclusive as to any overall trend in low-temperature groups.

\section{Parborlasia corrugatus}

There were no significant seasonal differences in faecal egestion, oxygen consumption or nitrogen excretion in Parborlasia corrugatus. Annual maximal factorial change in oxygen consumption was 1.7, ammonia factorial change was 2.5, and urea factorial change was 2.0, which are well within ranges reported previously (see Clarke \& Prothero-Thomas 1997). Feeding in $P$. corrugatus is reported to be continuous (i.e. throughout the year, Pearse et al. 1985). Like other Antarctic marine invertebrates, the duration of the of the specific dynamic action (SDA) response in $P$. corrugatus was more than 20 to 30 d (Clarke \& ProtheroThomas 1997), showing that it takes a long time for them to digest and assimilate food. After a large meal, $P$. corrugatus might not need to feed for weeks due to their low-energy lifestyle. Thus, feeding state is likely to have been very variable amongst the sampled specimens in the present study and in fact one $P$. corrugatus individual in October 2007 produced 22 times more 
faeces than the other 5 specimens. Its data point, however, was removed as an outlier value (test after Nalimov) before testing for seasonal differences. Nemertean worms are able to locate carrion quickly and form dense feeding aggregations in winter and summer (Smale et al. 2007) and take advantage of iceberg-scour food windfalls (probably the source of most carrion). Scouring events happen more often during the summer as winter fast ice, which locks icebergs in place, is absent (Smale et al. 2008), but scouring events are still unpredictable (Brown et al. 2004). Thus, the observed peak in faecal egestion in February 2008 could be the result of a scour event providing a localised food source.

Factors other than temperature are primarily responsible for the fluctuations in respiration and excretion (indicated by calculated non-biological $Q_{10}$ of 241.4). Changes in O:N ratios were mainly driven by changes in oxygen consumption. In contrast to the small changes in respiration and excretion, however, there was a significant seasonal difference in O:N ratios. The ratios for Parborlasia corrugatus were the lowest of all in the present study and similar to literature values (Boyce \& Clarke 1997). Such low O:N ratios indicate a highly protein-rich diet, which might suggest that the nemertean worms are the only true carnivores amongst the species investigated. It is interesting in this context that $P$. corrugatus is described as an opportunistic generalist with high food plasticity (Dearborn 1965, Gibson 1983, Pearse et al. 1991).

In summary, Parborlasia corrugatus exhibits an even pattern of its physiological processes, with only minor seasonal fluctuations in its O:N ratios. This shows that key influences are likely to be the periodicity of food availability, quality and quantity. Other factors such as reproductive activity probably play a minor role. $P$. corrugatus appears relatively uncoupled from the overall environmental seasonality many Antarctic herbivores are governed by.

\section{Paraceradocus miersii}

A rise in oxygen consumption by a factor of 1.2 and a factor of 2.7 change in ammonia excretion between winter and summer values were recorded in Paraceradocus miersii in the present study. The small seasonal change here does not reflect the significant increase from winter to summer observed in faecal egestion rates. Variability of feeding activity, however, was high, and animals in the field were not starved for a prolonged period as was, however, the case during an SDA response in the Antarctic scavenging amphipod Waldeckia obesa, yielding a 3 times higher rise in respiration and excretion (Chapelle et al. 1994).
Other factors influencing metabolic rates could be moulting (Chapelle et al. 1994) and reproduction. Ecdysis is periodic and can elevate oxygen consumption 2- to 6-fold above pre-moult levels and ammonia excretion 2- to 4-fold in Waldeckia obesa. Reproductive activity, such as brooding, observed in Paraceradocus miersii in the field during the present study, is however a prolonged process, and there is no single spawning event, which could drive metabolic rates to a significant but seasonally limited peak (Coleman 1989, Klages 1993).

Few data exist for ammonia and urea excretion in marine benthic (and demersal) crustaceans (Quarmby 1985, Chen \& Lin 1995, Durand et al. 2000, Lee \& Chen 2003) and even fewer for amphipods. To our knowledge, the present study is the first to report on data for urea excretion in Antarctic amphipods, and annual mean ammonia and urea excretion were close to ranges reported for temperate amphipods (Dresel \& Moyle 1950). In Paraceradocus miersii, a decrease in ammonia excretion drove the non-significant seasonal change in O:N ratio, leading to a higher value in September when faecal egestion was low. This uncoupling of feeding and metabolism may indicate reliance on stored reserves, which the O:N ratios suggest are lipids, which could even out some of the seasonal fluctuations. Mean O:N ratios of 30 to 62 recorded in the present study were within the range of both extreme nutritional states, severely starved and fed ad libitum ( 7 to $70 \pm 45$ ), induced in Waldeckia obesa in Chapelle et al. (1994), suggesting that, although feeding was variable, nutrition was available throughout the year. The amphipod genus Paraceradocus has been reported to preferably ingest detritus within sediment and krill meat only when starved during laboratory experiments (Coleman 1989). But Paraceradocus miersii also scavenges on the flesh of a wide range of species when maintained in laboratory aquaria (G. Chapelle pers. comm., M. Langridge pers. comm.). This mixed diet would result in variable O:N ratios found in the field.

In summary, Paraceradocus miersii has an even pattern of its physiological processes, with some seasonal influence on faecal egestion. Key influences are likely to be food availability and quality and to a lesser extent changes in life cycle (e.g. growth, moulting and reproduction).

\section{Doris kerguelenensis}

We measured a significant difference between winter and summer faecal egestion in Doris kerguelenensis. This seasonal pattern is striking because in contrast to the other species there is sufficient supply of its 
obligate food demosponges (Cattaneo-Vietti 1991, Barnes \& Bullough 1996) and hexactinellid sponges (Dayton 1979, Wägele 1989) all year round near Rothera to support continuous (ad libitum) feeding. $D$. kerguelenensis have a low predatory impact on their host sponge, allowing them to feed on the same sponge for many years (Dayton et al. 1974, Barnes \& Bullough 1996). This indicates that $D$. kerguelenensis is adapted for a very low-energy lifestyle and can survive prolonged periods on small or zero food intake. However, the overall mass of faeces produced was between 46 and 77 times lower in winter compared to summer. As food items are present at the same levels throughout the year, such a large seasonal variation in faecal production was unexpected. Although there are no seasonal evaluations of sponge-tissue energy content, they are generally considered to be a low-energy food source (Dayton et al. 1974) and the nutritional value of sponges may change sufficiently so that feeding is suppressed in winter.

Doris kerguelenensis exhibited the smallest annual factorial changes in metabolic rates of all investigated species in the present study. These changes were small also when compared to other Antarctic invertebrates (Peck 1998, Brockington 2001, Fraser et al. 2002). In D. kerguelenensis, like in all other species in the present study, the increase in metabolic rates observed was unlikely to have been caused by the very small increase in temperature $\left(0.4^{\circ} \mathrm{C}\right)$ between winter and the start of summer alone, as the respective $Q_{10}$ would amount to 22.9. Differences in feeding activity (i.e. faecal egestion) were the most likely cause for seasonally different respiration. Unfortunately, faecal egestion in the nudibranch was not measured before the onset of winter. Thus the higher oxygen consumption in March 2008 can not be correlated to the extent of feeding activity during the first summer. In the limpet Nacella concinna, oxygen consumption and nitrogen excretion also varied significantly between seasons, with lower values in winter and higher rates in summer (Fraser et al. 2002). However, the latter study showed that continuous feeding reduced the metabolic seasonality, although faecal egestion (feeding) was clearly lower in winter compared to summer.

Unlike the other study species, we cannot say whether reproductive activity of Doris kerguelenensis during the study period contributed to changes in metabolic rates. D. kerguelenensis is reported to have direct development with a long embryonic period (Wägele 1996, Hain 1998). Dorids are assumed to be semelparous (reproducing only once per lifetime) with reproduction occurring after the first 2 to $6 \mathrm{yr}$ (Miller 1962, Thompson 1964, Dayton et al. 1974) but it is not known whether D. kerguelenensis also only reproduces once per lifetime.
Doris kerguelenensis had the second lowest O:N ratios of all investigated species after the nemertean worms. But in contrast to Parborlasia corrugatus, D. kerguelenensis is highly specialised in its diet, feeding almost exclusively on demosponges (Cattaneo-Vietti 1991, Barnes \& Bullough 1996) and hexactinellid sponges (Dayton 1979, Wägele 1989). Changes in O:N ratios were caused by changes in ammonia excretion during summer months. As a single sponge species can dominate the nutrition of $D$. kerguelenensis during its lifetime, seasonal changes in the elemental composition of the food sponge may contribute more to changes in O:N ratios compared to the other study species, which have a far less specialised diet.

In summary, Doris kerguelenensis employs a mixture of seasonal strategies with significant seasonal patterns in some of its physiological processes; however, patterns are not consistent across parameter. $D$. kerguelenensis appears more coupled to the overall seasonality observed in Antarctic primary consumers. This may be indirectly caused by its nutritional specialisation on suspension feeders (sponges).

\section{CONCLUSIONS}

Antarctic secondary consumers have much more seasonally variable metabolic strategies than would be expected given a near-year round food supply that is not directly coupled to the environmental seasonality. Previous investigations of seasonal ecophysiology in polar marine benthic ectotherms have concentrated on primary consumers (e.g. Peck et al. 1987, Pearse et al. 1991, Barnes \& Clarke 1995, Ahn et al. 2001, Brockington 2001, Fraser et al. 2002, 2004). These have, with a notable few exceptions (e.g. Peck et al. 1987) found strong seasonal patterns in growth, feeding and metabolic characteristics, with many species exhibiting periods of quiescence in winter. These periods of quiescence are characterised by very low metabolic rates and a cessation of feeding of between 1 and 5 mo. The data obtained in the present study for feeding and metabolism for a range of scavenging and carnivorous species are variable in the extent of seasonality exhibited. The majority of the species here exhibited periods of a cessation of feeding and seasonally variable use of metabolic substrates but on the other hand did not reach levels of seasonal change in oxygen consumption and nitrogen excretion exhibited by several species of primary consumer. The hypothesis that members of the predator/scavenger feeding guild would be less markedly affected by environmental seasonality in all their physiological processes (as a whole) than benthic 'herbivores' or pelagic invertebrates (Clarke \& Peck 1991) has not been substantiated. Food availabil- 
ity for these secondary consumers was indeed more variable throughout the year than anticipated. The degree to which seasonality in food quality and quantity, reproduction and temperature affect the carnivores varies between species and individuals and results in a mixture of energetic responses. And no clear-cut line can be drawn between specialised or generalistic nor more predatory or scavenging feeding modes.

Acknowledgements. We thank the Rothera Research Station dive, boating and support teams from 2006 to 2009 for their help with collecting and maintaining the animals. This study forms part of the British Antarctic Survey Bioflame and Polar Science for Planet Earth programmes. It was funded by the Natural Environment Research Council. The authors confirm that sampling of all species and use of animals in experiments was in accordance with respective guidelines and permits.

\section{LITERATURE CITED}

Ahn IY, Chung H, Choi KS (2001) Some ecological features of the Antarctic clam, Laternula elliptica (King and Broderip) in a nearshore habitat on King George Island. Ocean Polar Res 23:419-424

Aronson RB, Thatje S, Clarke A, Peck LS, Blake DB, Wilga CD, Seibel BA (2007) Climate change and invisibility of the Antarctic benthos. Annu Rev Ecol Evol Syst 38: 129-154

Atkinson DE (1992) Functional roles of urea synthesis in vertebrates. Physiol Zool 65:243-267

Baldwin E (1967) Dynamic aspects of biochemistry, 5th edn. Cambridge University Press, Cambridge

Banse K (1987) Seasonality of phytoplankton chlorophyll in the central and northern Arabian Sea. Deep-Sea Res I 34: 713-723

Barnes DKA, Bullough LW (1996) Some observations of the diet and distribution of nudibranchs at Signy Island, Antarctica. J Molluscan Stud 62:281-287

Barnes DKA, Clarke A (1994) Seasonal variation in the feeding activity of four species of Antarctic bryozoan in relation to environmental factors. J Exp Mar Biol Ecol 181: 117-133

Barnes DKA, Clarke A (1995) Seasonality of feeding activity in Antarctic suspension feeders. Polar Biol 15:335-340

Barnes DKA, Conlan KE (2007) Disturbance, colonisation and development of Antarctic benthic communities. Philos Trans R Soc Lond B 362:11-38

Barnes DKA, Peck LS (2005) Extremes of metabolic strategy in Antarctic Bryozoa. Mar Biol 147:979-988

Barnes DKA, Webb KE, Linse K (2007) Growth rate and its variability in erect Antarctic bryozoans. Polar Biol 30: 1069-1081

Becerro MA, Turon X (1992) Reproductive cycles of the ascidians Microcosmus sabatieri and Halocynthia papillosa in the northwestern Mediterranean. PSZN I: Mar Ecol 13: 363-373

Bowden DA, Clarke A, Peck LS, Barnes DKA (2006) Antarctic sessile marine benthos: colonisation and growth on artificial substrata over three years. Mar Ecol Prog Ser 316:1-16

Bowden DA, Clarke A, Peck LS (2009) Seasonal variation in the diversity and abundance of pelagic larvae of Antarctic benthic marine invertebrates. Mar Biol 156: 2033-2047
Boyce SJ (1999) Nitrogenous excretion in the Antarctic plunderfish. J Fish Biol 54:72-81

Boyce SJ, Clarke A (1997) Effect of body size and ration on specific dynamic action in the Antarctic plunderfish Harpagifer antarcticus. Physiol Zool 70:679-690

Brett JR, Zala CA (1975) Daily pattern of nitrogen excretion and oxygen consumption of sockeye salmon (Oncorhynchus nerka) under controlled conditions. J Fish Res Board Can 32:2479-2486

Brockington S (2001) The seasonal energetics of the Antarctic bivalve Laternula elliptica (King and Broderip) at Rothera Point, Adelaide Island. Polar Biol 24:523-530

Brockington S, Clarke A (2001) The relative influence of temperature and food on the metabolism of a marine invertebrate. J Exp Mar Biol Ecol 258:87-99

$>$ Brockington S, Peck LS (2001) Seasonality of respiration and ammonia excretion in the Antarctic echinoid Sterechinus neumayeri. Mar Ecol Prog Ser 219:159-168

Brown KM, Fraser KPP, Barnes DKA, Peck LS (2004) Links between the structure of an Antarctic shallow-water community and ice-scour frequency. Oecologia 141:121-129

Cattaneo-Vietti R (1991) Nudibranch molluscs from the Ross Sea, Antarctica. J Molluscan Stud 57(Suppl 4):223-228

Chapelle G, Peck LS, Clarke A (1994) Effects of feeding and starvation on the metabolic rate of the necrophagous Antarctic amphipod Waldeckia obesa (Chevreux, 1905). J Exp Mar Biol Ecol 183:63-76

Chen CJ, Lin CY (1995) Responses of oxygen consumption, ammonia-N excretion and urea-N excretion of Penaeus chinensis exposed to ambient ammonia at different salinity and pH levels. Aquaculture 136:243-255

Clarke A (1983) Life in cold water: the physiological ecology of polar marine ectotherms. Oceanogr Mar Biol Annu Rev 21:341-453

Clarke A (1988) Seasonality in the Antarctic marine environment. Comp Biochem Physiol 90B:461-473

Clarke A (1990) Faecal egestion and ammonia excretion in the Antarctic limpet Nacella concinna (Strebel, 1908). J Exp Mar Biol Ecol 138:227-246

Clarke A, Johnston N (1999) Scaling of metabolic rate and temperature in teleost fish. J Anim Ecol 68:893-905

Clarke A, Leakey RJG (1996) The seasonal cycle of phytoplankton, macronutrients, and the microbial community in a nearshore Antarctic marine ecosystem. Limnol Oceanogr 41:1281-1294

> Clarke A, Peck LS (1991) The physiology of polar marine zooplankton. Polar Res 10:355-369

> Clarke A, Prothero-Thomas E (1997) The effect of feeding on oxygen consumption and nitrogen excretion in the Antarctic nemertean Parborlasia corrugatus. Physiol Zool 70:639-649

Clarke A, Holmes LJ, White MG (1988) The annual cycle of temperature, chlorophyll and major nutrients at Signy Island, South Orkney Islands, 1969-82. Br Antarct Surv Bull 80:65-86

> Clarke A, Prothero-Thomas E, Whitehouse MJ (1994) Nitrogen excretion in the Antarctic limpet Nacella concinna (Strebel, 1908). J Molluscan Stud 60:141-147

Clarke A, Prothero-Thomas E, Beaumont JC, Chapman AL, Brey T (2004) Growth in the limpet Nacella concinna from contrasting sites in Antarctica. Polar Biol 28:62-71

Clarke A, Meredith MP, Wallace MI, Brandon MA, Thomas DN (2008) Seasonal and interannual variability in temperature, chlorophyll and macronutrients in northern Marguerite Bay, Antarctica. Deep-Sea Res II 55:1988-2006

$>$ Coleman CO (1989) Burrowing, grooming, and feeding behaviour for Paraceradocus, an Antarctic amphipod 
genus (Crustacea). Polar Biol 10:43-48

Coma R, Ribes M, Gili JM, Zabala M (1998) An energetic approach to the study of life-history traits of two modular colonial benthic invertebrates. Mar Ecol Prog Ser 162: 89-103

> Coma R, Ribes M, Gili JM, Zabala M (2000) Seasonality in coastal benthic ecosystems. Trends Ecol Evol 15:448-453

Dahm C (1996) Ecology and population dynamics of Antarctic Ophiuroids (Echinodermata). Rep Polar Res 194:1-279

> Daniels RA (1978) Nesting Behaviour of Harpagifer bispinis in Arthur Harbour, Antarctic Peninsula. J Fish Biol 12: 465-474

Daniels RA (1979) Nest guard replacement in the Antarctic fish Harpagifer bispinis: possible altruistic behaviour. Science 205:831-833

Dayton PK (1979) Observations on growth, dispersal and population dynamics of some sponges in McMurdo Sound, Antarctica. In: Levi C, Boury-Esnault N (eds) Sponge biology, Vol 291. CNRS, Paris, p 273-282

- Dayton PK, Robilliard GA, Paine RT, Dayton LB (1974) Biological accommodation in the benthic community at McMurdo Sound, Antarctica. Ecol Monogr 44:105-128

Dearborn JH (1965) Ecological and faunistic investigations of the marine benthos at McMurdo Sound, Antarctica. PhD dissertation, Stanford University, Stanford, CA

> Degobbis D (1973) On the storage of seawater samples for ammonia determination. Limnol Oceanogr 18:146-150

> Dresel EIB, Moyle V (1950) Nitrogenous excretion of amphipods and isopods. J Exp Biol 27:210-225

> Durand F, Devillers N, Lallier FH, Regnault M (2000) Nitrogen excretion and changes in blood components during emersion of the subtidal spider crab Maia squinado (L.). Comp Biochem Physiol A 127:259-271

Fenchel T (1990) Adaptive significance of polymorphic life cycles in Protozoa: responses to starvation and refeeding in two species of marine ciliates. J Exp Mar Biol Ecol 136: 159-177

Fraser KPP, Clarke A, Peck LS (2002) Feast and famine in Antarctica: seasonal physiology in the limpet, Nacella concinna (Strebel, 1908). Mar Ecol Prog Ser 242:169-177

Fraser KPP, Peck LS, Clarke A (2004) Protein synthesis, RNA concentrations, nitrogen excretion, and metabolism vary seasonally in the Antarctic holothurian Heterocucumis steineni (Ludwig 1898). Physiol Biochem Zool 77:556-569

Fratt DB, Dearborn JH (1984) Feeding biology of the Antarctic brittle star Ophionotus victoriae (Echinodermata: Ophiuroidea). Polar Biol 3:127-139

Gibson R (1983) Antarctic nemerteans: the anatomy, distribution, and biology of Parborlasia corrugatus (McIntosh, 1876) (Heteronemertea, Lineidae). Antarct Res Ser 29: 289-316

Grange L, Tyler PA, Peck LS, Cornelius N (2004) Long-term interannual cycles of the gametogenic ecology of the Antarctic brittle star Ophionotus victoriae. Mar Ecol Prog Ser 278:141-155

Gruzov EN (1977) Seasonal alterations in coastal communities in the Davies Sea. In: Llano G (ed) Adaptations within ecosystems. Smithsonian Press, Washington, DC, p 263-278

Hain S (1998) Beiträge zur Biologie der beschalten Mollusken (Kl. Gastropoda \& Bivalvia) des Weddellmeeres, Antarktis. $\mathrm{PhD}$ thesis, University of Bremen, Bremen

- Hanamura Y, Siow R, Chee PE (2008) Reproductive biology and seasonality of the Indo-Australasian mysid Mesopodopsis orientalis (Crustacea: Mysida) in a tropical mangrove estuary, Malaysia. Estuar Coast Shelf Sci 77: $467-474$

Harrington RJ (1986) Growth patterns within the genus Pro- tothaca (Bivalvia: Veneridae) from the Gulf of Alaska to Panama: palaeotemperatures, palaeobiogeography and palaeolatitudes. PhD thesis, University of California, Santa Barbara, CA

> Heilmayer O, Brey T, Pörtner HO (2004) Growth efficiency and temperature in scallops: a comparative analysis of species adapted to different temperatures. Funct Ecol 18: 641-647

Hochachka PW (1991) Temperature: the ectothermy option In: Hochachka PW, Mommsen TP (eds) Biochemistry and molecular biology of fishes, Vol. 1. Elsevier Science Publishers, Amsterdam, p 313-322

Holmes RM, Aminot A, Kerouel R, Hooker BA, Peterson BJ (1999) A simple and precise method for measuring ammonium in marine and freshwater ecosystems. Can J Fish Aquat Sci 56:1801-1808

Hop H, Graham M (1995) Respiration of juvenile arctic cod (Boreogadus saida): effects of acclimation, temperature, and food intake. Polar Biol 15:359-367

Hughes RN (1989) A functional biology of clonal animals. Chapman \& Hall, London

Janecki T, Rakusa-Suszczewski S (2006) Biology and metabolism of Glyptonotus antarcticus (Eights) (Crustacea: Isopoda) from Admiralty Bay, King George Island, Antarctica. Polar Biosci 19:29-42

Jobling M (1994) Fish bioenergetics. Chapman \& Hall, London

Klages M (1993) Distribution, reproduction and population dynamics of the Antarctic gammaridean amphipod Eusirus perdentatus Chevreux, 1912 (Crustacea). Antarct Sci 5:349-359

> Lee WC, Chen JC (2003) Hemolymph ammonia, urea and uric acid levels and nitrogenous excretion of Marsupenaeus japonicus at different salinity levels. J Exp Mar Biol Ecol 288:39-49

> Lehtonen KK (1996) Ecophysiology of the benthic amphipod Monoporeia affinis in an open-sea area of the northern Baltic Sea: seasonal variations in oxygen consumption and ammonia excretion. Mar Biol 126:645-654

Lobel PS (1978) Diel, lunar and seasonal periodicity in the reproductive behavior of the Pomacanthid fish, Centropyge potteri, and some other reef fishes in Hawaii. Pac Sci 32:193-207

Longhurst A (1993) Seasonal cooling and blooming in tropical oceans. Deep-Sea Res I 40:2145-2165

- Mayzaud P, Conover RJ (1988) O:N atomic ratio as a tool to describe zooplankton metabolism. Mar Ecol Prog Ser 45: 289-302

Miller MC (1962) Annual cycles of some Manx nudibranchs with a discussion of the problem of migration. J Anim Ecol 31:545-569

Morley SA, Peck LS, Tan KS, Martin SM, Pörtner HO (2007) Morphological temperature compensation maintains burrowing capacity: a latitudinal comparison in the bivalve Laternula. Mar Biol 151:1823-1830

Nicol JAC (1967) The biology of marine animals, 2nd edn. Wiley-Liss, New York, NY

Pearse JS (1965) Reproductive periodicities in several contrasting populations of Odontaster validus Koehler, a common Antarctic asteroid. Antarct Res Ser 5:39-85

Pearse JS, Bosch I, McClintock JB (1985) Contrasting modes of reproduction by common shallow-water Antarctic invertebrates. Antarct J US 30:138-139

Pearse JS, McClintock JB, Bosch I (1991) Reproduction of Antarctic marine benthic invertebrates: tempos, modes and timing. Am Zool 31:65-80

Peck LS (1998) Feeding, metabolism and metabolic scope in 
Antarctic ectotherms. Soc Exp Biol Sem Ser 66:365-389

Peck LS, Barnes DKA (2004) Metabolic flexibility: the key to long-term evolutionary success in Bryozoa? Proc R Soc Lond B 271(Suppl 3):S18-S21

Peck LS, Conway LZ (2000) The myth of metabolic cold adaptation: oxygen consumption in stenothermal Antarctic bivalves. In: Harper EM, Taylor JD, Crame JA (eds) The evolutionary biology of the Bivalvia. Spec Publ 177. Geological Society, London, p 441-445

Peck LS, Clarke A, Holmes L (1987) Summer metabolism and seasonal biochemical changes in the brachiopod Liothyrella uva (Jackson, 1912). J Exp Mar Biol Ecol 114:85-97

Peck LS, Brockington S, Brey T (1997) Growth and metabolism in the Antarctic brachiopod Liothyrella uva. Philos Trans R Soc Lond B 352:851-858

Peck LS, Barnes DKA, Willmott J (2005) Responses to extreme seasonality in food supply: diet plasticity in Antarctic brachiopods. Mar Biol 147:453-463

Peck LS, Convey P, Barnes DKA (2006) Environmental constraints on life histories in Antarctic ecosystems: tempos, timings and predictability. Biol Rev Camb Philos Soc 81: 75-109

Picken GB (1980) The distribution, growth, and reproduction of the Antarctic limpet Nacella (Patinigera) concinna (Strebel, 1908). J Exp Mar Biol Ecol 42:71-85

Quarmby LM (1985) The influence of temperature and salinity on the nitrogenous excretion of the spot prawn, Pandalus platyceros Brandt. J Exp Mar Biol Ecol 87:229-239

Rahmatullah M, Boyde TRC (1980) Improvements in the determination of urea using diacetyl monoxime; methods with and without deproteinisation. Clin Chim Acta 107:3-9

Rakusa-Suszczewski S (1982) The biology and metabolism of Orchomene plebs (Hurley 1965) (Amphipoda: Gammaridea) from McMurdo Sound, Ross Sea, Antarctic. Polar Biol 1:47-54

Ramon M, Abello P, Richardson CA (1995) Population structure and growth of Donax trunculus (Bivalvia: Donacidae) in the western Mediterranean. Mar Biol 121:665-671

Editorial responsibility: James McClintock, Birmingham, Alabama, USA
Reed SE (1995) Reproductive seasonality, periodicity, and associated behaviour in a colony of Strombus pugilis (Mollusca: Gastropoda) in Puerto Rico. Am Malacol Bull 11: $117-121$

Robertson RF, El-Haj AJ, Clarke A, Peck LS, Taylor EW (2001) The effects of temperature on metabolic rate and protein synthesis following a meal in the isopod Glyptonotus antarcticus, Eights (1852). Polar Biol 24:677-686

Smale D, Barnes DKA, Fraser KPP, Mann PJ, Brown MP (2007) Scavenging in Antarctica: intense variation between sites and seasons in shallow benthic necrophagy. J Exp Mar Biol Ecol 349:405-417

Smale DA, Brown KM, Barnes DKA, Fraser KPP, Clarke A (2008) Ice scour disturbance in Antarctic waters. Science 321:371

Stott FC (1934) Marine plankton: seasonal cycles. J Anim Ecol 3:112-113

Tanner JE (1996) Seasonal and lunar periodicity in the reproduction of Pocilloporid corals. Coral Reefs 15:59-66

Thompson TE (1964) Grazing and the life cycles of British nudibranchs. In: Crisp DJ (ed) Grazing in terrestrial and marine environments. Br Ecol Symp 4. Blackwell Publishing, Oxford, p 275-297

Turon X (1992) Periods of non-feeding in Polysyncraton lacazei (Ascidiacea:Didemnidae): a rejuvenative process? Mar Biol 112:647-655

> Wägele H (1989) Diet of some Antarctic nudibranchs (Gastropoda, Opisthobranchia, Nudibranchia). Mar Biol 100: 439-441

Wägele H (1996) On egg clutches of some Antarctic Opisthobranchia. Molluscan reproduction. Malacol Rev Suppl 6:21-30

Whitaker TM (1982) Primary production of phytoplankton off Signy Island, South Orkneys, the Antarctic. Proc R Soc Lond B 214:169-189

Wood CM (1993) Ammonia and urea metabolism and excretion. In: Evans DH (ed) The physiology of fishes. CRC Press, Boca Raton, FL, p 177-230

Submitted: February 2, 2010; Accepted: July 16, 2010 Proofs received from author(s): September 17, 2010 